NBER WORKING PAPER SERIES

HOUSEHOLD LOCATION DECISIONS AND THE VALUE OF CLIMATE AMENITIES

\author{
Paramita Sinha \\ Maureen L. Cropper \\ Martha Caulkins \\ Working Paper 21826 \\ http://www.nber.org/papers/w21826 \\ NATIONAL BUREAU OF ECONOMIC RESEARCH \\ 1050 Massachusetts Avenue \\ Cambridge, MA 02138 \\ December 2015
}

We thank the US Environmental Protection Agency, RTI International, and Resources for the Future for funding. This paper would not have been possible without the excellent research assistance of Martha Caulkins and GIS support from RTI. The views expressed herein are those of the authors and do not necessarily reflect the views of the National Bureau of Economic Research.

NBER working papers are circulated for discussion and comment purposes. They have not been peer-reviewed or been subject to the review by the NBER Board of Directors that accompanies official NBER publications.

(C) 2015 by Paramita Sinha, Maureen L. Cropper, and Martha Caulkins. All rights reserved. Short sections of text, not to exceed two paragraphs, may be quoted without explicit permission provided that full credit, including $\odot$ notice, is given to the source. 
Household Location Decisions and the Value of Climate Amenities

Paramita Sinha, Maureen L. Cropper, and Martha Caulkins

NBER Working Paper No. 21826

December 2015, Revised January 2017

JEL No. Q5,Q51

\begin{abstract} avoid the B1 scenario and 2.4 percent of income to avoid the A2 scenario.

Paramita Sinha

Research Triangle Institute

701 13th Street, NW

Suite 750

Washington, DC 20005-3967

psinha@rti.org

Maureen L. Cropper

Department of Economics

University of Maryland

College Park, MD 20742

and NBER

cropper@econ.umd.edu

Martha Caulkins

University of Maryland

caulkins@econ.umd.edu
\end{abstract}

We value climate amenities by estimating a discrete location choice model for US households. The utility of each metropolitan statistical area (MSA) depends on location-specific amenities, earnings opportunities, housing costs, and the cost of moving to the MSA from the household head's birthplace. We use the estimated trade-off among wages, housing costs, and climate amenities to value changes in mean winter and summer temperatures. We find that households sort among MSAs as a result of heterogeneous tastes for winter and summer temperatures. Preferences for winter and summer temperatures are negatively correlated: households that prefer milder winters, on average, prefer cooler summers, and households that prefer colder winters prefer warmer summers. Households in the Midwest region, on average, have lower marginal willingness to pay to increase winter and reduce summer temperatures than households in the Pacific and South Atlantic census divisions. We use our results to value changes in winter and summer temperatures for the period 2020 to 2050 under the B1 (climate-friendly) and A2 (more extreme) climate scenarios. On average, households are willing to pay 1 percent of income to 


\title{
Household Location Decisions and the Value of Climate Amenities
}

\author{
Paramita Sinha, Martha L. Caulkins and Maureen L. Cropper*
}

\section{Introduction}

The amenity value of climate - what people are willing to pay to experience warmer winters or avoid hotter summers - is an important component of the benefits of greenhouse gas mitigation policies. Yet, with the exception of Albouy et al. (2016), the recent literature contains few estimates of the value of climate amenities for the United States. Estimating these values poses an econometric challenge: climate, by definition, changes slowly, so researchers must rely on cross-sectional variation in climate to measure its impact on household location decisions. This paper helps fill this gap by estimating a discrete location choice model in which a household's choice of the city in which to live depends on climate amenities as well as earnings, housing costs, and other location-specific amenities. We use the model to estimate household willingness to pay (WTP) for changes in mean winter and summer temperatures and use these values to assess the welfare effects of temperature changes in cities throughout the United States.

Traditionally, economists have used hedonic wage and property value functions to value climate amenities (Cragg and Kahn 1999; Gyourko and Tracy 1991; Blomquist et al. 1988; Smith 1983). In a world in which households can migrate costlessly across cities, locationspecific amenities should be capitalized into wages and property values. In equilibrium, each household will select a city (i.e., a vector of amenities) so that the marginal cost of obtaining each amenity, measured in terms of wages and housing costs, just equals the value it places on the amenity (Roback 1982). ${ }^{1}$ This approach has been followed most recently by Albouy et al. (2016), who regress a quality of life (QOL) index - a weighted sum of wage and price ind icesfor each public-use microdata area (PUMA) on a vector of location-specific amenities, including climate amenities.

\footnotetext{
*Paramita Sinha, RTI International, psinha@rti.org; Martha L. Caulkins, University of Maryland, caulkins@econ.umd.edu; Maureen Cropper, University of Maryland and Resources for the Future, cropper@rff.org. We thank the US Environmental Protection Agency, RTI International, and Resources for the Future for funding. This paper would not have been possible without GIS support from RTI.

${ }^{1}$ Formally, marginal WTP for an amenity equals the sum of the slope of the hedonic wage function with respect to the amenity plus the slope of the hedonic property value function, weighted by the share of income spent on housing, evaluated at the chosen amenity vector (Roback 1982).
} 
An alternate approach to valuing amenities that vary by location is to estimate a discrete choice model of household location decisions (Bayer et al. 2004; Bayer and Timmins 2007; Bayer et al. 2009; Cragg and Kahn 1997; Klaiber and Phaneuf 2010). Households choose among locations based on the utility they receive from each location, which depends on wages, housing costs, and location-specific amenities. Variations in wages, housing costs, and amenities across locations permit identification of the parameters of the household's utility function.

The discrete choice approach, which we follow here, offers several advantages over the traditional hedonic approach. Most important, it allows the researcher to more easily incorporate market frictions, including the psychological and informational costs of moving. ${ }^{2}$ The hedonic approach assumes that consumers are perfectly mobile and hence that the weighted sum of wage and housing price gradients will equal the consumer's marginal willingness to pay (MWTP) for an amenity. Bayer et al. (2009) demonstrate that this equality fails to hold in the presence of moving costs, and they incorporate the psychological and informational costs of leaving one's birthplace into an equilibrium model of household location choice. We also incorporate moving costs from birthplace in our model of location choice and demonstrate that their omission significantly understates the value consumers place on temperature and precipitation.

The discrete choice approach allows us to obtain exact welfare measures for changes in temperature throughout the United States based on two climate scenarios. These welfare measures incorporate both taste sorting based on climate and the opportunity for households to move in response to changes in temperature.

\section{Our Approach}

In this paper, we value climate amenities by estimating a model of residential location choice among metropolitan statistical areas (MSAs) for US hous eholds in 2000. We model the choice among MSAs based on potential earnings, housing costs, moving costs, climate amenities, and other location-specific amenities. The model is estimated as a mixed logit model, which allows the coefficients on climate amenities to vary among households. We compute the means of these coefficients for each household, conditional on choice of MSA, and then examine

\footnotetext{
${ }^{2}$ Barriers to mobility prevent the sum of wage and housing price gradients from equaling marg inal willingness to pay, and they imply that the assumption of national labor and housing markets, which underlies the hedonic approach, may not accurately capture wage and housing costs in different cities.
} 
how the average conditional mean MWTP for climate amenities varies across MSAs to describe taste sorting.

We value future changes in temperature in two ways. We use the conditional mean MWTPs to compute the value of changes in temperature assuming that each household does not move. This is analogous to the value of temperature changes computed by Albouy et al. (2016) based on local linear estimates of the hedonic price function. We also compute exact welfare measures (i.e., expected compensating variation) using each household's conditional distribution of taste coefficients. These measures implicitly allow households to move in response to temperature changes.

Our paper builds on the work of Cragg and Kahn (1997), who were the first to use a discrete choice approach to value climate amenities. ${ }^{3}$ We extend their work, following Bayer et al. (2009), by including moving costs and modeling choices across MS As. Unlike Bayer et al., however, we cannot use multiple cross sections to difference out unobserved amenities within cities. Historical data indicate that climate changes slowly, forcing us to rely on a single cross section of data rather than data over consecutive decades. ${ }^{4}$ We attempt to allay concerns about omitted variable bias by controlling for a wide variety of location-specific amenities other than temperature, especially those that are correlated with temperature.

\section{Our Findings}

Our results indicate that households are willing to pay to avoid cold winter temperatures and hot summer temperatures; however, these values vary significantly by residential location. We find a strong positive correlation between MWTP for winter temperature and the temperature of the city in which the household lives: households with the highest MWTP for warmer winters live in Florida, while those with the lowest MWTP live in the Midwest. Preferences for summer temperature and winter temperature are, however, negatively correlated $(\rho=-0.83)$. This implies that households that prefer milder winters, on average, also prefer milder summers, while households that prefer colder winters have a lower MWTP to reduce summer temperatures. MWTP to avoid hotter summers is, on average, higher for households who live in the South Atlantic and Pacific regions than in the Midwest. At the level of census regions, households who

\footnotetext{
${ }^{3}$ Cragg and Kahn (1997) value climate a menities by estimating a model of the choice of state in which to live for households that moved between 1985 and 1990.

4 This is also true of the literature that examines the impact of climate on agriculture (Schlenker and Rob erts 2009).
} 
live in the Midwest and Northeast have lower MWTPs to increase winter and reduce summer temperatures than households who live in the South and West.

We use these estimates to value changes in mean summer and winter temperatures over the period 2020 to 2050 for 284 US cities that contained over 80 percent of the US population in 2000. The Hadley model projects that, under the B1 climate scenario from the Special Report on Emissions Scenarios (SRES), ${ }^{5}$ mean summer temperature (population weighted) will increase, on average, by $3.3^{\circ} \mathrm{F}$ in these cities and mean winter temperature by $3.4^{\circ} \mathrm{F}$. Cities in the New England and Middle Atlantic states will experience larger increases in winter temperature than in summer temperature, although the reverse is true for the East South Central and West South Central census divisions, and also the Pacific and Mountain states. Ignoring sorting overstates the WTP of households in the New England and Middle Atlantic states for the B1 scenario and greatly unders tates the value of avoiding the B1 scenario to households in the Midwest. On net, allowing for taste sorting increases the average household WTP to avoid the B1 scenario by 29 percent compared with a world in which sorting is ignored.

Allowing for sorting actually decreases the average household WTP to avoid the more severe A2 scenario. The A2 scenario results in very large increases in summer temperature in the East and West South Central divisions and the Midwest region. Ignoring sorting overstates the disamenity of the A2 scenario in the Midwest and South census regions.

Taking sorting into account, the mean household WTP to avoid the B1 scenario in the 2020-2050 timeframe is about 1 percent of income; it is about 2.4 percent of income for avoiding the $\mathrm{A} 2$ scenario. We note that the latter value is within the range reported by Albouy et al. (2016) for a much more drastic climate scenario in the period 2090-2099. ${ }^{6}$ One possible reason for the difference in estimates is that we base our estimates on all households, whereas Albouy et al. (2016) focus on prime-aged households. Our results suggest that the value attached to climate amenities varies with the age of the household head: on average, households with heads over the age of 55 have a MWTP for higher winter temperature and a MWTP to avoid

\footnotetext{
5 To represent a range of driving forces for emissions, such as demographic development, socioeconomic development, and technological change, the Intergovernmental Panel on Climate Change (IPCC) developed a s et of emissions scenarios. In the SRES, IPCC (2000) describes these scenarios in more detail. We use projections from a climate-friendly scenario (B1) and a more extreme scenario (A2).

6 Albouy et al. (2016) focus on the A2 scenario in the period 2090-2099, when it is expected to raise mean temperature in the United States by $8.3^{\circ} \mathrm{F}$ compared with the $1970-2000$ period.
} 
increased summer temperature that is about twice as high as households with heads between 25 and 55 years old. For policy purposes, we focus on results based on all households.

The paper is organized as follows. Section 2 presents the household's location decision and the econometric models we estimate. Section 3 describes the data used in our analysis. Estimation results are presented in Section 4. Section 5 uses these results to evaluate the value of temperature changes projected by the B1 and A2 SRES scenarios. Section 6 concludes the paper.

\section{Household Residential Location Model}

We model household location in 2000 assuming that each household selected its preferred MSA from the set of MSAs in the United States in $2000 .{ }^{7}$ Household utility depends on income minus the cost of housing, location-specific amenities, and moving costs from the birthplace of the household head. Specifically, we assume that the utility that household $i$ receives from city $j$ is given by

$$
U_{i j}=\alpha\left(Y_{i j}-P_{i j}\right)+\boldsymbol{A}_{j} \boldsymbol{\beta}_{i}+M C_{i j}
$$

where $Y_{i j}$ is household $i$ 's income and $P_{i j}$ its housing expenditure in city $j . M C_{i j}$ represents the costs - psychological and other - of moving from the head of household's birthplace to city $j$. Going forward, we refer to these as "moving costs." $\boldsymbol{A}_{j}$ is a vector of location-specific amenities. Equation (1) assumes that household utility is linear in the Hicksian bundle (i.e., $Y_{i j}-P_{i j}$ ). We relax this assumption below; however, linearity in the Hicksian bundle simp lifies the computation of welfare measures.

Household income is the sum of the wages of all workers in the household, $W_{i j}$, plus nonwage income, which is assumed not to vary by residential location. To predict the earnings of household workers in locations not chosen, we estimate hedonic wage and housing price equations for each MSA, as described below.

\footnotetext{
${ }^{7}$ Because we focus on the choice of MSA, we are estimating the climate preferences of people who live in urban areas.
} 
We allow the coefficients on temperature amenities to vary across households. ${ }^{8}$ We hypothesize that households vary in their tastes for climate, and sort across MSAs based on taste differences. In our base case, summer and winter temperature enter the utility function linearly: we assume a constant marginal utility of temperature, and estimate a household's willingness to pay for small changes in temperature at their chosen location. As a sensitivity analysis, we allow marginal utility to vary non-linearly with temperature.

Moving costs capture the psychological, search, and out-of-pocket costs of leaving a household's place of origin. Seventy-three percent of households in our sample (see Table 1, full sample) live in the census region in which the head was born; 67 percent live in the same census division. Although households have been moving to warmer weather since the Second World War (Rappaport 2007), family ties and informational constraints may have prevented this from occurring more completely. As shown below, failure to account for these costs significantly alters the value attached to winter and summer temperatures.

In our base case, following Bayer et al. (2009), we represent moving costs as a series of dummy variables that reflect whether city $j$ is outside of the state, census division, or census region in which household $i$ 's head was born. Formally,

$$
M C_{i j}=\pi_{0} d_{i j}^{\text {State }}+\pi_{1} d_{i j}^{\text {Division }}+\pi_{2} d_{i j}^{\text {Region }}
$$

where $d_{i j}$ State denotes a dummy variable that equals one if $j$ is in a state that is different from the one in which household head $i$ was born, $d_{i j}^{\text {Division }}$ equals 1 if location $j$ is outside of the census division in which the household head was born, and $d_{i j}{ }^{\text {Region }}$ equals 1 if location $j$ lies outside of the census region in which the household head was born.

We also allow for two alternate specifications of moving costs. In one specification, we replace the dummy variables in equation (2) by the log of the distance from the populationweighted centroid of the household head's birthplace state to the population-weighted centroid of the state, division, and region where the household resides. In the other specification, we allow moving costs to vary with the presence of children (following Hamilton and Phaneuf 2015) and

\footnotetext{
${ }^{8} \mathrm{We}$ choose to estimate a random coefficients model rather than using household characteristics to explain heterogeneous preferences across households. Estimating a random coefficients model allows us to compute the distribution of marginal utility of summer and winter te mperature (and, hence, marginal willingness to pay), conditional on a household's chosen location. We believe that this is more relevant for evaluating climate policy than computing marg inal willingness to pay as a function of household characteristics.
} 
marital status. This controls for the idea that different households may have different moving costs; for example, married households may be constrained by finding a city that can accommodate two workers, and households with children may be resistant to relocate their children while school-aged. Specifically, we interact the geographic dummies in equation (2) with variables ind icating whether the household contains any children and whether the household head is married.

\section{Estimation of the Model}

Estimating the location choice model requires information on the wages that a household would earn and the cost of housing in all MSAs. Because wages are observed only in the household's chosen location, we estimate a hedonic wage equation for each MSA and use it to predict $W_{i j}$. The hedonic wage equation for MSA $j$ regresses the logarithm of the hourly wage rate for worker $\mathrm{m}$ in MSA j on variables $\left(\boldsymbol{X}_{m j}^{w}\right)$ measuring the demo graphic characteristicseducation, experience, and industry and occupation — of worker m:

$$
\ln w_{m j}=\gamma_{j}^{w}+\boldsymbol{X}_{m j}^{w} \boldsymbol{\Gamma}^{w}+v_{m j}^{w} \quad \forall j=1, \ldots, J
$$

Equation (3) is estimated using data on full-time workers in the public use microdata sample (PUMS). ${ }^{9}$ The coefficients of equation (3) are used to calculate the earnings of each worker in the sample used to estimate the discrete choice model, under the assumption that individuals work the same number of hours and weeks in all locations. Summing earnings over all individuals in each household, we obtain predicted household wages for household $i$ in location $j$ $\left(\hat{W}_{i j}\right)$. Predicted income in city $j, \widehat{Y}_{i j}$ equals predicted wage income plus non-wage income of household $i$, which is assumed not to vary by MSA.

\footnotetext{
${ }^{9}$ The equation is estimated using data on all persons working at least 40 weeks per year and between 30 and 60 hours per week. Persons who are self-employed, in the military, or in farming, fishing, or forestry are excluded from the sample. We have also estimated equation (3) allowing for non-random sorting (Dahl 2002). Specifically, we compute the probability of moving from each birthplace to current location (in terms of census divisions) conditional on each education group listed in Table 1 by taking the appropriate cell counts in our sample of workers (close to 3 million individuals). Including this probability correction term (in quadratic form) in equation (3) has minimal impact on our wage regression results, possibly due to the inclusion of industry and occupation indicators in the equation. The Dahl correction terms are significantly different from zero in only 26 percent of the 284 MSA wage regressions. Further, very few coefficients are affected by the inclusion of the correction terms - the most affected coffecients are "High School" and "So me Co llege" but these change only by 5-6 percent on average. Because the correction terms are rarely significant and have little qualitative impact, we elect to use equation (3) without Dahl corrections to predict wages for our discrete choice model.
} 
The cost of housing in each location is estimated based on hedonic property value equations for each MSA,

$$
\ln P_{i j}=\gamma_{j}^{P}+\boldsymbol{X}_{i j}^{P} \boldsymbol{\Gamma}^{P}+v_{i j}^{P} \quad \forall j=1, \ldots, J
$$

$P_{i j}$ is the annual cost of owning house $i$ in city $j$, computed as the sum of the imputed monthly mortgage payment or rent and the cost of utilities, property taxes, and property insurance. ${ }^{10} \boldsymbol{X}_{i j}^{P}$ contains a dummy variable indicating whether the house was owned or rented, as well as a vector of dwelling characteristics. Utility costs are added both to the costs of owning a home and to rents because heating and cooling requirements vary with climate. We wish to separate these costs from climate amenities. Equation (4) is estimated separately for each MSA in our dataset.

We predict housing expenditures for household $i$ in city $j\left(\widehat{P}_{i j}\right)$ assuming that the household purchases the same bundle of housing characteristics in city $j$ as it purchases in its chosen city. This is clearly a strong assumption. To test its validity, we examine the mean value of key housing characteristics (number of bedrooms and number of rooms) and their standard deviation across MSAs, for different household groups, characterized by income group and household size. The coefficient of variation for number of bedrooms and number of rooms within income and household size groups averages only $0.07-0.08$, suggesting that households of similar size and income tend to live in dwellings of similar characteristics, thus supporting our methodology for predicting housing expenditures. ${ }^{11}$

The results of estimating the individual MSA hedonic wage and housing market equations for our base case are summarized in Appendix Tables A-1 and A-2. We find, as do Cragg and Kahn (1997), that the coefficients in both sets of hedonic equations vary significantly across MSAs, suggesting that the assumption of national labor and housing markets made in hedonic studies is inappropriate.

\footnotetext{
10 The monthly mortgage payment for each house represents the opportunity cost of owning the house. It is imputed, based on the owner-ass ess ed value of the house and average mortgage interest rates in 2000. It does not represent the actual payment made by the owner of the house.

11 As a sensitivity analysis we estimate a location choice model that uses a housing price index, following Bayer et al. (2009), rather than predicting housing expenditures in each MSA. In Bayer et al. (2009), utility is assumed to be of the Cobb Douglas form, imply ing that indirect utility is a function of a housing price index that varies across cities, not hous eholds. The housing price index for each MSA is the estimated MSA fixed effect in a national hedonic housing price equation. (See Appendix B for further details.)
} 
We estimate the discrete location choice model in two stages. The first is a mixed logit model in which the indirect utility function incorporates unobserved heterogeneity in preferences for winter and summer temperature, and MSA fixed effects $\left(\delta_{j}\right)$ :

$$
V_{i j}=\alpha\left(\hat{Y}_{i j}-\hat{P}_{i j}\right)+W T_{j} \beta_{i}^{W T}+S T_{j} \beta_{i}^{S T}+M C_{i j}+\delta_{j}+\varepsilon_{i j}
$$

We assume that the temperature coefficients $\left(\beta^{W T}\right.$ and $\left.\beta^{S T}\right)$ are jointly normally distributed, with mean vector $\boldsymbol{\mu}$ and variance-covariance matrix $\boldsymbol{\Sigma}$. The elements of $\boldsymbol{\Sigma}$ are estimated in the first stage. However, since the MSA fixed effects encompass all local attributes that do not vary across households, the mean vector $\boldsymbol{\mu}$ is contained in $\delta_{j}$, and thus, is estimated in the second stage. The error term in the household's utility function $\varepsilon_{i j}$ combines the error in predicting household $i$ 's wages and housing expenditures in city $j$ with household $i$ 's unmeasured preferences for city $j$. Assuming that the idiosyncratic errors are independently and identically distributed Type I extreme value, the probability of household $i$ selecting city $j$ is given by the mixed logit model. The parameters of equation (5) are estimated via simulated maximum likelihood techniques, using a choice set equal to the household's chosen alternative and a random sample of 59 alternatives from the set of 284 MS As. ${ }^{12}$

In the second stage, city-specific fixed effects are regressed on the vector of amenities to estimate the means of the temperature coefficients and the coefficients on other amenities:

$$
\delta_{j}=\boldsymbol{A}_{j} \Gamma+u_{j}
$$

\section{Data}

The data used to estimate our location model, hedonic wage equations, and hedonic housing equations come from the 5 percent PUMS of the 2000 US census as well as other publicly available data sources.

\footnotetext{
12 The valid ity of the McFadden sampling procedure (McFadden 1978) hinges on the independence of irrelevant alternatives, which does not hold in the mixed logit model. We do, however, face computational trade-offs in estimating the mixed logit model using all 284 elements of the universal choice set and a sample large enough to estimate 284 fixed effects with precision. Experiments with the size of the choice set indicated that increasing the size of the choice set beyond 60 MSAs did not significantly alter parameter estimates. In estimat ing equation (5) the means of $\beta^{W T}$ and $\beta^{S T}$ are constrained to be zero.
} 


\section{Sample Households}

To select the sample used to estimate our location choice models, we focus on households residing in one of the 284 MSAs for which we have complete amenity data. These MSAs contained 80 percent of the total US population in 2000. To be included, a household must be headed by a person 16 years of age or older who was born in the continental United States. We exclude households with heads in the military or in certain occupations (e.g., logging, mining) that would restrict locational choices. We also eliminate households with members who are self-employed, due to difficulty in predicting their wages, and households with negative Hicksian bund les at their chosen locations. ${ }^{13}$

Table 1 describes the characteristics of our sample households and of subsets of these households. We estimate the discrete choice model for the full sample of households and also for the two subsamples described in Table 1: households with prime-aged heads (i.e., heads between 25 and 55) and households with heads over age 55. Amenity values presented in this paper focus on the full sample. Estimates in the hedonics literature, which use wage and housing cost differentials to value amenities, are usually based on prime-aged adults. The reason for this is clear: 98 percent of households with prime-aged heads have some labor income, and on average, 93 percent of the income of these households comes from wages. Forty-seven percent of older households have no wage income.

A striking fact in Table 1 is that a large percentage of households continue to live in the area where the household head was born. Fifty-seven percent of all households live in the state where the head was born, 66 percent in the same census division, and 73 percent in the same census region. This foreshadows the importance of moving costs (birthplace location) in explaining residential location choice.

\section{Climate Variables}

The climate variables in our model are summarized in Table 2. All variables are climate normals: the arithmetic mean of a climate variable computed for a 30 -year period. ${ }^{14}$

\footnotetext{
${ }^{13}$ Hous eholds with negative Hicksian bundles may have substantial accu mulated wealth (e.g., in real property) that we cannot measure. There are 2,162,570 households in the PUMS that satisfy our criteria for sample inclusion.

14 The temperature and summer precipitation data are for the period 1970 to 2000. July relative humidity, annual snowfall, and percentage possible sunshine are measured for the period 1960 to 1990 .
} 
We focus on mean temperature, measured for the winter (December-February) and summer (June-August) seasons. Previous studies of climate amenities have used primarily mean winter and summer temperatures or annual heating and cooling degree days. ${ }^{15}$ In studying the impact of climate on agriculture, health, and electricity usage, temperature has been measured by the number of days in various temperature bins (Schlenker and Roberts 2009; Deschenes and Greenstone 2011; Albouy et al. 2016). The advantage of mean winter and summer temperatures is that they capture seasonality, which annual heating and cooling degree days and temperature bins do not. At the same time, correlation between winter and summer temperatures and temperatures during other seasons of the year means that winter and summer temperatures will pick up other temperature impacts: the correlation between mean winter temperature and mean March temperature is 0.97 , as is the correlation between mean winter temperature and mean November temperature. Collinearity among mean winter, summer, fall, and spring temperatures, however, makes it impossible to include all four measures in our models.

The precision with which the impact of temperature on location decisions can be estimated depends on temperature variation. Mean winter temperature across the 284 MSAs in our data averages $37^{\circ} \mathrm{F}$, with a standard deviation (s.d.) of $12^{\circ}$; summer temperature averages $73^{\circ}$, with an s.d. of $6^{\circ}$. Winter and summer temperatures are highly correlated $(r=0.76)$.

The models presented in the next section include annual snowfall, mean summer precipitation, and July relative humidity. Mean winter precipitation, which averages 9.4 inches (s.d. $=5$ inches), is highest in the Pacific Northwest and the Southeast, where winter precipitation comes in the form of rain. In preliminary analyses, winter precipitation appeared to be a disamenity, but this effect was statistically significant only at low levels of precipitation. This suggested that snowfall should replace winter precipitation: cities with significant snowfall have lower levels of winter precipitation (the correlation between annual snowfall and winter precipitation is -0.36 ), and snow is likely to be more of a disamenity than rain.

Summer precipitation, which averages 11 inches (s.d. $=5$ inches), is heaviest in the Southeast United State. Surprisingly, the correlation between summer precipitation and winter

\footnotetext{
15 Heating and cooling degree days are computed by the National Climatic Data Center using the average of the high and low temperatures for a day. If this is greater than $65^{\circ} \mathrm{F}$, it results in (average temperature - 65) cooling degree days. If the average temperature is less than $65^{\circ}$, it results in ( 65 - average temperature) heating degree days. Graves and Mueser (1993) and Kahn (2009) use mean January and mean July temperatures; Cragg and Kahn (1997, 1999) use mean February and mean Ju ly temperatures. Roback (1982), Blomquist et al. (1988), and Gyourko and Tracy (1991) use annual heating and cooling degree days, as do Albouy et al. (2016).
} 
precipitation is very low $(\mathrm{r}=0.03)$, as is the correlation between summer precipitation and annual snow $(\mathrm{r}=-0.02)$. Mean July relative humidity is 69 percent (s.d. $=7$ percent) and is not highly correlated with either winter temperature $(r=0.06)$ or summer temperature $(r=0.14)$.

Following the literature, we also include the percentage of possible sunshine, defined as the total time that sunshine reaches the surface of the earth, expressed as a percentage of the maximum amount possible from sunrise to sunset.

\section{Nonclimate Amenities}

The nonclimate amenity variables used in the second stage of the model are also summarized in Table 2. These include amenity measures typically used in quality-of-life studies, as well as variables that are likely to be correlated with climate, such as elevation, visibility, and measures of parks and recreation opportunities. Our desire is to be as inclusive as possible. Because climate changes slowly, we cannot use panel data to value climate amenities. We therefore strive to avoid problems of omitted variable bias by including a variety of locationspecific amenities in our models.

Many quality-of-life studies include population density as an amenity variable (Roback 1982; Albouy 2012) or city population (Gyourko and Tracy 1991). Population should be used with caution in a discrete choice model, since the model is constructed to predict the share of population in each city (i.e., summing the predicted probability of moving to city $j$ across households yields the predicted share of population in city $j$ ). We therefore do not include population as an amenity, but we do include population density, which may proxy amenities the higher population density supports that are not adequately captured by other amenities (better public transportation, restaurants, and live sporting events). We also estimate models with population density omitted.

Cragg and Kahn (1997) in estimating a model of choice of state to live in include the number of cities within each state as a measure of the number of location choices available to residents. We follow their lead by including the number of counties in each MSA. We also estimate models in which population density is replaced by land area, after Bartik (1985), who uses land area as a proxy for abundance of location choices. Other amenities and disamenities for which we control include air pollution (fine particulate matter [PM2.5]), an index of violent crime, visibility (percentage of hours with visibility greater than 10 miles), square miles of parks within the MSA, elevation measured at the population-weighted centroid of the MSA, and distance from the population-weighted centroid of each MSA to the nearest coast. We also include indices from the Places Rated Almanac (Savageau and D'Agostino 2000) that measure 
how well each city functions in terms of transportation, education, health, and recreation opportunities.

\section{Estimation Results}

\section{Discrete Location Choice Models}

Table 3 describes our base model (Model 1) results for all households, prime-aged households, households with heads older than 55, and movers. The base model is a mixed logit model that allows the coefficients on winter and summer temperatures to be jointly normally distributed and controls for the first 18 attributes in Table 2, as well as the Hicksian bundle and the moving costs as specified in equation (2). Coefficients on the climate variables have been converted to MWTP by dividing by the coefficient on the Hicksian bundle. For winter and summer temperatures, we report the mean and standard deviation of the distribution of MWTP, as well as the correlation coefficient between the winter and summer temperature coefficients. ${ }^{16}$

The most striking result in the table is that the mean MWTP for winter and summer temperatures differ significantly across samples. While all groups, on average, view higher winter temperature as an amenity and higher summer temperature as a disamenity, the absolute magnitudes of MWTP are much greater for older households than for prime-aged households. Mean MWTP for a $1^{\circ}$ increase in winter temperature is about twice as high for older households as for prime-aged households (\$1,035 vs. \$518). ${ }^{17}$ At the same time, older households are, on average, willing to pay much more to decrease summer temperature than prime-aged households (\$1,424 vs. \$627). Mean MWTP to increase winter or decrease summer temperature by $1^{\circ}$ is about 40 percent higher using the full sample than prime-aged households. These results underscore the importance of considering all households when evaluating climate impacts for policy purposes.

The models for all three age cohorts indicate considerable variation in tastes for winter and summer temperatures. The standard deviations of the coefficients for winter and summer temperatures are large. For the all-household and older-household samples, there is greater

\footnotetext{
16 Tables 3 through 5 report MWTP only for climate variables. MWTPs for all base model coefficients are reported in Appendix Table A-3. Although we focus on the impacts of summer and winter temperatures, we note that all other amenities except particulate matter and sunshine have expected signs and are statistically significant.

${ }^{17}$ In interpreting MWTP, it should be remembered that this represents the value of a $1^{\circ}$ increase in temperature each day over three winter months and also captures milder temperatures in adjacent months.
} 
variation in the coefficient on winter than the coefficient on summer temperature. The temperature coefficients in all cases are negatively correlated: most households that prefer milder winters also prefer milder summers, while those that favor colder winters like hotter summers. ${ }^{18}$

The last model in Table 3 is estimated using households that moved between 1995 and 2000. Cragg and Kahn (1997) focus on recent movers to value climate change using the 1990 PUMS. In previous work, we have also focused on recent movers (Sinha and Cropper 2013). Table 3 confirms that movers indeed have different preferences for climate amenities than households in the full sample, which includes households that stayed in the same location. The mean MWTP of movers for winter temperature is, on average, 39 percent higher than the mean MWTP of households in the full sample and 90 percent higher than prime-aged households, who more closely resemble movers in terms of demographic characteristics. ${ }^{19}$

Calculating the benefits of policies to avoid climate change should be based on the location decisions of all households. We therefore focus on the full sample of households for the remainder of the paper.

Table 4 shows the sensitivity of results for the full sample to the specification of moving costs. It is variation in moving costs across households (as well as variation in wages and housing expenditures) that allows us to identify the parameters of our model; hence, it is important to see how our results vary with changes in moving costs. In Model 2, where moving costs are modeled as the log of distance between birthplace and residence locations, MWTP is qualitatively the same, though there are some small differences in magnitude. For example, weighting moving costs by $\log$ (distance) increases the amenity value of winter temperature from $\$ 709$ to $\$ 790$ and lowers the amenity value of summer precipitation from $\$ 376$ to $\$ 254$.

Interacting the moving cost terms with dummy variables for the presence of children and marital status (Model 3) has little impact on results-MWTPs for climate amenities change by less than $\$ 10$.

18 The negative correlation implies that there are some people who are very sensitive to outdoor temperature --if someone values warmer winters more than the average person then they also value milder summers more than the average person--and those people who are not very sensitive: they are willing to pay less for warm winters and also don't mind hotter summers.

19 The MWTP of movers for a $1^{\circ}$ decrease in summer temperature is 27 percent higher than in the full sample and 77 percent higher than in the prime-aged sample. 
We note that if moving costs are removed from the model entirely (Model 4), the marginal value of climate amenities falls and households no longer appear to differ in their preferences for winter temperature, that is, the standard deviation on winter temperature becomes statistically insignificant. Omitting moving costs also reduces (in absolute value) MWTP for winter and, especially, for summer temperatures, as well as precipitation, snow fall, and humidity. These results support Bayer et al.'s (2009) assertion that ignoring moving costs may significantly alter WTP for location-specific amenities. The results also suggest that moving costs may have prevented households from moving to warmer weather. Table 4 thus confirms the importance of including moving costs in the discrete choice model.

Table 5 shows the impact on the coefficients of winter and summer temperatures of alternate specifications of amenities for the full sample: dropping population density (Model 5); replacing population density with land area (Model 6); adding the number of counties in the MSA to the model (Mode1 7), and removing other climate variables (Model 8). ${ }^{20}$ As noted in Section 3, MSA population is not included as an amenity because the discrete choice model is a share model-aggregating the probability that city $j$ is chosen across all households yields the share of population predicted to live in that city. Population density is included as a proxy for amenities that are made possible by higher population density but not captured by the Places Rated Almanac. Nonetheless, population density is correlated with population. Dropping population density leaves the mean MWTP for a $1^{\circ}$ change in winter and summer temperatures virtually unchanged. They are \$709 and $-\$ 873$ in Model 1 and \$748 and -\$849 in Model 5. Similarly, replacing population density with land area has little impact on the base model: MWTP for winter temperature and summer temperature are $\$ 725$ and $-\$ 890$, respectively, in Model 6. Adding the number of counties to the base specification affects MWTP estimates a bit more, but results remain qualitatively the same. Specifically, MWTP for winter temperature increases to $\$ 815$ while summer temperature falls to $-\$ 848$. Model 8 shows the importance of controlling for other climate variables when valuing temperature. When July humidity, summer precipitation, sunshine, and snowfall are omitted, mean MWTP for winter temperature rises by over 70 percent (to $\$ 1,237$ ), while mean MWTP for summer temperature falls slightly (to -

\footnotetext{
${ }^{20} \mathrm{We}$ also estimated a model in which we included squared temperature terms in the second stage estimation. The summer temperature coeffic ients were insignificant, and the implied MWTP estimates were similar to those from our base case. These results are available upon request.
} 
\$820). Further sensitivity analyses suggest that when snowfall is omitted, winter temperature picks up its effects, whereas summer temperature is sensitive to July humidity. ${ }^{21}$

Appendix Table A-4 shows the impact of alternate specifications of the Hicksian bundle. In Mode19, we include a quadratic term for the Hicksian bundle in the first stage of the model. When evaluated at the mean Hicksian bundle MWTPs for all climate amenities fall in absolute value, by about 15 percent for winter and summer temperature and by about 20 percent for the other climate variables. In contrast, we obtain larger MWTP estimates in Model 10, where we follow the Bayer et. al. (2009) housing price index approach (described in detail in Appendix B). Here, the log of total income replaces the Hicksian bundle in the first stage, while the second stage dependent variable is now the MSA fixed effect from the first stage adjusted by the citylevel housing price index. MWTPs for all climate variables are higher in this sensitivity analysis - about 20 percent higher for the temperature terms and approximately 50 percent higher for the other climate variables. Specifically, MWTP for winter temperature rises from $\$ 709$ in the base case to $\$ 885$ in Model 10, while the MWTP for avoiding summer temperature increases in magnitude from $-\$ 873$ to $-\$ 1,004$.

\section{Taste-Based Sorting}

To examine how households sort across locations in relation to their taste for winter and summer temperature, we use Model 1 to calculate the joint distributions of the coefficients of winter and summer temperature for each household, conditional on the household's choice of location. The means of these conditional distributions are averaged across all sample households in each MSA, divided by the coefficient on the Hicksian bundle, and plotted against MSA temperature in Figures 1 and $2 .{ }^{22}$

To compute conditional household-level parameters, we follow the procedure of Revelt and Train (1999), who uses Bayes' Rule to derive the conditional distribution of the temperature coefficients (i.e., conditional on chosen location, choice ${ }_{i}$; observable household attributes, $Z_{i}$, which include the Hicksian bundle and moving costs; and the overall distribution of temperature parameters, $f(\beta \mid \mu, \Sigma))$ :

21 These sensitivity analys es are available upon request from the authors.

22 When preferences for winter and summer temperatures are forced to be uncorrelated, there is a strong association between MSA mean MWTP for higher temperature and temperature itself - the correlation is 0.96 between MSA mean MWTP for winter temperature and 0.97 between MSA mean MWTP for summer temperature. It appears (incorrectly) that households in warmer cities place higher values on both summer and winter temperatures. 


$$
h\left(\beta \mid \text { choice }_{i}, Z_{i}, \mu, \Sigma\right)=\frac{\operatorname{Pr}\left(\text { choice }_{i} \mid Z_{i}, \beta\right) f(\beta \mid \mu, \Sigma)}{\operatorname{Pr}\left(\text { choice }_{i} \mid Z_{i}, \mu, \Sigma\right)}
$$

Taking the expectation of this conditional distribution reveals an expression for household-level parameters, or the mean taste parameters, $\mu_{i}$, of households of type $Z_{i}$, such that

$$
\mu_{i}=E\left(\beta_{i} \mid \text { choice }_{i}, Z_{i}, \mu, \Sigma\right)=\int \beta_{i} h\left(\beta \mid \text { choice }_{i}, Z_{i}, \mu, \Sigma\right) d \beta
$$

These household-level parameters are estimated via simulation. Taking the average over all households in each MSA and dividing by the coefficient on the Hicksian bundle yields average MWTP for all households in a given MS A. Formally, the MWTP for winter temperature in MSA $j$ is

$$
M W T P_{j}^{W T}=\frac{1}{N_{j}} \sum_{i} \mathbf{1}\left[i \text { resides in } M S A_{j}\right]\left(\beta_{i}^{W T} / \alpha\right)
$$

where $N_{j}$ is the number of households in MSA $j$.

As seen in Figure 1, there is a strong correlation between MWTP for warmer winters and MSA temperature (the correlation coefficient between MSA winter temperature and mean MWTP is 0.93), indicating that, other things equal, households sort across cities based on preferences for milder winters. Specifically, households with higher than average MWTP for winter temperature have located in warmer cities and households with lower than average MWTP for winter temperature have located in colder cities. ${ }^{23}$ The median WTP for a $1^{\circ}$ increase in winter temperature in the coldest 142 cities (those with mean winter temperature below $35^{\circ}$ ) is $\$ 223$; in the warmest 142 cities, it is $\$ 1,184$. The city with the lowest MWTP for warmer winters is Fargo, North Dakota; Palm Beach and Naples, Florida, have the highest MWTP.

There is, however, some variation in mean MWTP across cities holding temperature constant. For example, at a mean winter temperature of $40^{\circ}$, households in Oregon and Washington states have a willingness to pay for a warmer winter that is over four times as high as the MWTP of households in Texas. At a mean winter temperature of $50^{\circ}$, households in San Francisco and San Jose, California, are willing to pay approximately $\$ 700$ more for a $1^{\circ}$ increase in warmer winter temperature than households in Charleston, South Carolina.

\footnotetext{
${ }^{23}$ Recall that MWTP for winter temperature is assumed constant.
} 
Preferences for warmer winters vary, on average, by census division, as indicated in Figure 1 and Panel B ofFigure 3, and confirmed by Table 6, which shows mean MWTP averaged across the MSAs in each census division, weighted by MSA population. ${ }^{24}$ MWTP for warmer winters is, on average, negative in the West North Central division; it is also below the mean for the country in the East North Central division and the Middle Atlantic and New England states. MWTP for warmer winters is highest in the Pacific and South Atlantic census divisions. There is, however, considerable variation within divisions. MWTP is higher in California (especially in San Francisco, San Jose, Santa Barbara, and Orange County) than in Oregon and Washington states. It is much higher in Florida, especially in southern Florida, than in the other South Atlantic states; for example, MWTP in Savannah, Georgia, is half that of Miami.

The relationship between MWTP for a $1^{\circ}$ increase in summer temperature (Figure 2) and summer temperature is an inverted U. While MWTP for an increase in summer temperature is negative in all cities except Fargo, North Dakota, households in the Pacific and South Atlantic divisions have the greatest MWTP to reduce mean summer temperature by $1^{\circ} .25$ The disamenity value of a $1^{\circ}$ increase in mean summer temperature is greatest in absolute value in Palm Beach and Naples, F lorida $(-\$ 2,194)$ and somewhat lower in San Francisco $(-\$ 1,825)$ and San Jose, California $(-\$ 1,884) .{ }^{26}$ There is also considerable variation in MWTP at a given temperature. At a temperature of $70^{\circ}$, households on the Pacific coast find warmer summers a disamenity; however, this is less so for people in the West North Central division (e.g., the Dakotas). This is also true at mean summer temperatures above $80^{\circ} \mathrm{F}$ : households in the South Atlantic division find warmer summers a disamenity, but residents of Texas are willing to pay less to avoid hotter summers than residents of Florida.

\footnotetext{
24 The average MWTP for winter temperature and summer temperature in Table 6 ( $\$ 819$ for winter and $-\$ 940$ for summer temperature), conditional on location, differ from the un conditional values in Table 3 ( $\$ 709$ for winter and $\$ 873$ for summer temperature) because the former are weighted by MSA population. There is a positive correlation between MWTP for winter temperature and city population (0.11) and between MWTP for lower s ummer temperature and city population (0.10). Weighting by city population thus raises average MWTP. When conditional mean MWTP for winter temperature and summer temperature are averaged across all sample households rather than by city population, the results are $\$ 703$ and $-\$ 875$, respectively, which are very close to the unconditional values reported in Table 3.

25 The correlation between mean summer temperature and MWTP for summer temperature in Figure 2 is -0.38 . If we restrict preferences over winter and summer temperatures to be uncorrelated, we find a strong positive correlation between MWTP for summer temperature and the temperature of the city in which the household lives see footnote 21 .

${ }^{26}$ We emphasize that these calculations assume a constant MWTP for temperature as a function of temperature.
} 
Figures 1 through 3 and Panel A of Table 6 suggest that, holding temperature constant, MWTP for winter and summer temperatures varies by geographic region: households in the East North Central census division appear to find hotter summers less of a disamenity than households on the Pacific coast. Households in the Mountain states appear to favor colder winters than households in the Pacific division. Some of this might appear to reflect differences in other climate variables besides temperature, such as summer humidity, precipitation, and snowfall. Our base model, however, controls for summer humidity, precipitation, snowfall, and sunshine. Indeed, Model 8 ind icates the importance of controlling for other climate variables: when they are omitted from the model, the mean of the coefficient distribution on winter temperature increases by 75 percent.

In summary, although there is considerable variation within census regions, households who have located in the Midwest and the Northeast appear less sensitive to changes in temperature than households who live in the South and West. This suggests that when valuing changes in climate, ignoring taste sorting may cause warmer winters in the Northeast and Midwest to be overvalued and the value of lowering summer temperature in the South and West to be underestimated.

\section{Willingness to Pay for Future Projected Temperature Changes}

We use the results of the location choice model to estimate what households would pay for temperature changes that are projected to occur over the period 2020 to 2050 under two SRES climate scenarios. Specifically, we use the results of the Hadley III model to project mean winter and summer temperatures over the 2020 to 2050 period in our 284 MSAs under the B1 and A2 SRES scenarios. ${ }^{27}$ We estimate WTP for these temperature changes, compared with climate averages over the period 1970 to 2000 . We first compute WTP by multiplying the conditional mean MWTP for summer and winter temperature s in each MSA by the size of the temperature change. This assumes that households do not move in response to changes in temperature and provides valuations comparable with those produced by hedonic models. We also compute expected compensating variation for temperature changes using distribution of $\left(\beta^{W T}, \beta^{S T}\right)$ for each household, conditional on its location choice.

\footnotetext{
${ }^{27}$ Data from the Hadley III model were generously provided by Wolfram Sch lenker.
} 


\section{The B1 and A2 SRES Scenarios}

The B1 SRES scenario, a more climate-friendly scenario than A2, leads to an atmospheric carbon dioxide $\left(\mathrm{CO}_{2}\right)$ concentration of 550 parts per million $(\mathrm{ppm})$ in the year 2100, whereas the $\mathrm{A} 2$ scenario results in an atmospheric $\mathrm{CO}_{2}$ concentration of 850 ppm by 2100 (Karl et al. 2009). Over the period 2020 to 2050, however, the temperature projections for the United States do not differ dramatically between the two scenario ${ }^{28}{ }^{28}$ Both scenarios project warmer winters and warmer summers; however, the B1 scenario projects, on average, warmer winters than the A2 scenario for the $284 \mathrm{MSAs}$ - an average increase in winter temperature of $3.4^{\circ} \mathrm{F}$ under $\mathrm{B} 1$ and $2.1^{\circ} \mathrm{F}$ under A2. ${ }^{29}$ Projections of increases in summer temperature are slightly higher under the $\mathrm{A} 2$ scenario (on average, $\left.3.6^{\circ} \mathrm{F}\right)$ than under the $\mathrm{B} 2$ scenario $\left(3.3^{\circ} \mathrm{F}\right)$.

The variation in temperature changes across regions is, however, considerable. Figure 4 and Panel B of Table 6 show the population-weighted average winter and summer temperature changes for each scenario by census division. Panel B of Table 7 shows temperature changes by census region. The Northeast and Midwest regions and the South Atlantic division experience larger increases in winter temperature than increases in summer temperature under the B1 scenario. Cities in the New England and Middle Atlantic states experience the largest increases in winter temperature $\left(4.5^{\circ} \mathrm{F}\right.$ and $5.1^{\circ} \mathrm{F}$, respectively), followed by the Midwest region (East North Central, $3.7^{\circ} \mathrm{F}$; West North Central, 3.6 $\left.{ }^{\circ} \mathrm{F}\right)$. The South Atlantic states experience winter temperature increases of about $3.1^{\circ} \mathrm{F}$.

The remainder of the South (the West South Central [WSC] and East South Central [ESC] divisions) and the Mountain and Pacific divisions are hurt by the B1 scenario: households in these areas, on average, experience larger increases in summer than in winter temperature. The ESC and WSC divisions (which include Texas, Louisiana, Mississippi, and Alabama) suffer the greatest increases in summer temperature (an average of $5.5^{\circ} \mathrm{F}$ in the WSC), followed by states in the Mountain and Pacific census divisions. Summer temperatures increase by an average of $3.7^{\circ} \mathrm{F}$ in the Mountain and $3.1^{\circ} \mathrm{F}$ in the Pacific census divisions.

\footnotetext{
28 Other authors have focused on the damages as sociated with climate change at the end of this century, rather than midcentury (Albouy et al. 2016; Deschenes and Greenstone 2011). We focus on smaller, midcentury temperature changes for two reasons. First, changes of the magnitude examined by Albouy et al. (2016) would call for general equilibrium responses that we cannot model. They would result in major changes in wages and housing prices across cities. Second, our model is designed to value marg inal temperature changes, rather than nonmarginal changes.

29 These are population-weighted average temperature changes.
} 
All census divisions experience greater increases in summer than in winter temperature under the A2 scenario; however, the areas that suffer the least are the Northeast and the South Atlantic states. Increases in winter temperature under A2, which average $2.1^{\circ} \mathrm{F}$, are fairly uniform geographically. Summer temperature increases are below the national average of $3.6^{\circ} \mathrm{F}$ in the Northeast and South Atlantic states, approximately equal to the average in the West and Midwest, and highest in the ESC and WSC states.

\section{WTP Conditional on Current Location}

Table 6 and Figure 5 display household WTP for each SRES scenario, conditional on the household's current location. For each scenario, we multiply the summer and winter temperature changes in each MSA by the average conditional mean MWTP for that MSA (i.e., by the values shown in Figures 1 and 2). WTP is averaged across MS As within each census division (weighted by MSA population) and is also computed (population-weighted) for all 284 MS As. Table 7 displays the corresponding averages, by census region. Positive values indicate a positive WTP for the climate scenario, while negative values, indicating WTP to avoid the climate scenario, appear in parentheses. To see how taste sorting affects WTP for temperature changes, we also compute WTP using average household MWTP for summer and winter temperatures (displayed in the last column of Panel A of the table). These values are labeled WTP ignoring sorting.

Averaged across all MSAs, household WTP for the B1 scenario is negative and equal to about 1 percent of average household income; under the A2 scenario, it is also negative and is equal to about 2.4 percent of income; however, the distribution of WTP differs greatly across regions. Households in the Middle Atlantic and South Atlantic states are willing to pay a positive amount for the B1 scenario; households in the New England division have the smallest negative WTP for this scenario. This reflects the magnitude of increases in winter temperature in these areas, relative to increases in summer temperature. On the other hand, households in other parts of the South (the West South Central census division) have the highest negative WTP to avoid the B1 scenario, reflecting the much higher average increases in summer than in winter temperature in these states. Households in the East and West South Central divisions also have the highest WTP to avoid the A2 scenario - about 60 percent more than the MSA average. In general, WTP to avoid the A2 scenario differs less across regions than under the B1 scenario; however, households in the South Atlantic have a WTP to avoid A2 that is less than half the MSA average.

How would estimates of the value of climate change be altered if sorting were ignored and WTP imputed based on mean MWTP for summer and winter temperatures? Sorting, which 
implies that MWTP for winter and summer temperatures differ by region, has the biggest impact on the aggregate WTP for climate amenities when temperature changes are unevenly dis tributed across geographic regions, and areas experiencing extreme temperature changes value them very differently from the mean household. Aggregate climate damages will be understated if temperature changes are negatively correlated with MWTP to increase winter temperature or reduce summer temperature. This is indeed the case in the B1 scenario: the New England, Middle Atlantic, and East North Central divisions are all expected to experience above-average increases in winter temperature, but households in these regions value these changes much less than the mean household. Because the benefits of warmer winters are overstated when sorting is ignored, the resulting aggre gate WTP to avoid the B1 scenario is understated-by about 30 percent. 30

The impact of sorting on aggregate WTP is less pronounced under the A2 scenario because winter temperature changes are more evenly distributed geographically, and households in the areas that are expected to experience the biggest increases in summer te mperatures (the East South Central and West South Central divisions) value these temperature changes about the same as the mean household. Ignoring sorting when valuing the A2 scenario overstates aggregate damages only slightly (by 7 percent) primarily because ignoring sorting overstates the damages of the A2 scenario in the South Atlantic states.

\section{Exact Welfare Calculations}

The WTP estimates in Tables 6 and 7 and Figure 5 assume that households must remain in their current MSA when temperatures change. This should, on average, overstate the amount households would pay to avoid the two climate scenarios, given that households can move in response to changes in temperature. We would not, a priori, expect these adjustments to be large, given that we are evaluating small temperature changes and given the importance of moving costs in the discrete choice model. We do, however, calculate exact welfare measures, which allow for the possibility of migration.

A household's compensating variation for a change in summer and winter temperatures $\left(C V_{i}\right)$ is implicitly defined by the amount that can be taken away from the household when $S T$ and WT change, as shown in the following equation:

\footnotetext{
30 This is due primarily to impacts on winter temperature. The areas of the country that experience the greatest increases in summer temperature value them at a rate close to mean MWTP.
} 


$$
\begin{aligned}
& \max _{j}\left[\alpha\left(\hat{Y}_{i j}-\hat{P}_{i j}\right)+W T_{j}^{0} \beta_{i}^{W T}+S T_{j}^{0} \beta_{i}^{S T}+M C_{i j}+\delta_{j}+\varepsilon_{i j}\right] \\
= & \max _{j}\left[\alpha\left(\hat{Y}_{i j}-\hat{P}_{i j}-C V_{i}\right)+W T_{j}{ }^{1} \beta_{i}^{W T}+S T_{j}^{1} \beta_{i}^{S T}+M C_{i j}+\delta_{j}+\varepsilon_{i j}\right]
\end{aligned}
$$

We compute the expected value of $C V_{i}$ conditional on the household's choice of MSA - that is, using the distributions of $\left(\beta^{W T}, \beta^{S T}\right)$ and $\left\{\varepsilon_{i j}\right\}$ that are conditional on the household's observed choice of MSA:

$$
E\left(C V_{i} \mid k \text { chosen }\right)=\int C V_{i} f\left(\beta_{i}, \varepsilon_{i} \mid k \text { chosen }\right) d \beta_{i} d \varepsilon_{i}
$$

(von Haefen 2003). We simulate $E\left(C V_{i}\right)$ following von Haefen (2003) by taking a draw from the conditional distributions of random coefficients and the vector of error terms $\varepsilon_{i j}$ and computing $C V_{i}$ using equation (10) for each draw. We average these values across 100 draws to compute the household's expected compensating variation.

Table 8 and Figure 6 display $E\left(C V_{i}\right)$ for the $\mathrm{B} 1$ and $\mathrm{A} 2$ scenarios by census division. As in Table 6, average $E\left(C V_{i}\right)$ is averaged over all households in each MSA; MSA values are then weighted by population to yield census division averages. WTP estimates from Table 6, which are computed assuming that each household cannot change location, are presented for comparison. In all cases, $E(C V)$ is less than WTP: ${ }^{31}$ households, on average, require less compensation to endure an adverse climate scenario or - in the case of households in the South Atlantic and Middle Atlantic states under B1 - are willing to pay more for a climate scenario that they view as an improvement when they can change locations to adjust to the scenario.

The difference between expected compensating variation and WTP conditional on location is, however, small: allowing households to change location lowers the value of avoiding the B1 scenario by about 16 percent and the value of avoiding the A2 scenario by about 3 percent compared with Table 6 . Averaged across all households, the value of avoiding the climate scenarios using exact welfare measures is $\$ 574$ for the B1 scenario (0.91 percent of average household income) and \$1,492 for the A2 scenario (2.36 percent of average household income).

\footnotetext{
31 McFadden (1999) proves that this result must hold in random utility models employing the generalized extreme value distribution.
} 


\section{WTP Comparison with the Literature}

As do Cragg and Kahn (1997) and Sinha and Cropper (2013), we find that households value warmer winters, cooler summers, more rainfall, and less humidity. Cragg and Kahn (1997) model the choice of state in which to reside, while Sinha and Cropper (2013) model location choice at the MSA level. In agreement with Cragg and Kahn (1997), we find that MWTP for warmer winters and cooler summers increases with age. Overall, the results of our models agree qualitatively with previous studies using the discrete choice approach to valuing climate amenities.

In contrast, our estimates of the welfare losses associated with climate change are larger than those reported by Albouy et al. (2016) using a hedonic approach. Albouy et al. (2016) regress a weighted average of wages (net of taxes) and housing prices on local amenities using data from the 2000 PUMS. They find that households are willing to pay more to reduce cooling degree days than heating degree days and that the marginal disutility to reduce severe heat is not

statistically different from the marginal disutility to reduce moderate heat. When these results are used to value temperature changes associated with the A2 scenario in 2090 to 2099 — changes that average $8.3^{\circ} \mathrm{F}$-welfare losses are 2.24 percent of household income assuming homogeneous preferences and 2.87 percent allowing for heterogeneous preferences. We find comparable values for much milder temperature changes, on the order of $4^{\circ} \mathrm{F}$.

There are several possible reasons for the difference in magnitude of our results. The hedonic approach uses the capitalization of amenities into wages and housing prices to value amenities. This may be appropriate for prime-aged households that receive most of their income from wages, but it needs to be applied with caution in the case of older households that do not. The discrete choice approach allows for the fact that income may not vary much across MSAs for retirees, who may nevertheless sort across MSAs in response to differences in climate. It is the number of households that have located in each MSA, holding MSA characteristics constant, which identifies the parameters of household utility functions in the discrete choice approach. Our results indicate that it is important to take the preferences of older households (those with heads over 55 years of age) into account when evaluating temperature changes. If we were to base our estimates of the value of avoiding the B1 and A2 scenarios solely on prime-aged households, our estimates would fall by over 37 percent in the case of the B1 scenario and 34 percent in the case of the A2 scenario.

A second reason for the difference between the two sets of estimates derives from differences in assumptions about household mobility. Bayer et al. (2009) note that adding moving costs to a hedonic model destroys the equivalence between a household's MWTP for a 
local amenity and the capitalization of that amenity into wages and housing prices. Whether the capitalization of an amenity into wages and housing prices over- or understates MWTP is an empirical question. We note that removing moving costs from our location choice model causes the absolute value of MWTP for climate amenities to fall, suggesting that moving costs may have prevented climate amenities from being fully capitalized into wages and housing costs. Removing moving costs from our model causes the value of reducing summer temperature to fall by almost 50 percent.

\section{Conclusions}

The discrete location choice model that we have estimated indicates that climate amenities play an important role in household location decisions in the United States. The rate of substitution between household income net of housing costs and winter and summer temperatures is statistically significant, holding constant summer precipitation, snowfall, and July humidity. But there is considerable variation in MWTP for winter and summer temperatures across households. In general, households with a higher MWTP for warmer winters have located in MSAs with higher mean winter temperatures, such as MSAs in Florida or California, while tho se with the lowest MWTP live in the Midwest. Preferences for summer temperature and winter temperature are, however, negatively correlated $(\rho=-0.83)$. This implies that households that prefer milder winters, on average, also prefer milder summers, while households that prefer colder winters have a lower MWTP to reduce summer temperatures. MWTP to avoid hotter summers is, on average, higher in the South Atlantic and Pacific regions than in the Midwest. At the level of census regions, households in the Midwest and Northeast have lower MWTPs to increase winter and reduce summer temperatures than households in the South and West.

These sorting patterns have important implications for valuing avoided climate change. Under future warming scenarios, winter temperature is likely to increase the most at northern latitudes, specifically in the Midwest and Northeast. Since these regions have lower-than-average MWTP for warmer winters when allowing for sorting, using average MWTP for warmer winters for the entire United States is likely to overstate the value of warmer winters under most climate scenarios. At the same time, households' WTP to avoid hotter summers is greatest in the areas that are expected to experience about average increases in summer temperature - the South and parts of Southern California. Thus using average MWTP for cooler summers will understate the value of avoiding hotter summers implied by the A2 and B1 scenarios. Together these results suggest that ignoring taste sorting could understate the value of avoid ing climate change. 
Taking sorting into account, we estimate the value of avoiding two climate scenarios in the near term (2020-2050). We find that, aggregated over the entire United States, WTP to avoid the more climate-friendly B1 scenario is approximately 1 percent of household income, while it is approximately 2.4 percent of household income for the A2 scenario. The A2 scenario we consider would result in an average increase of $3.6^{\circ} \mathrm{F}$ in summer temperature and of $2.1^{\circ} \mathrm{F}$ in winter temperature. Estimates for the United States of market-based damages associated with climate change have typically been in the range of 1 percent of gross domestic product for an increase in mean temperature of $2^{\circ} \mathrm{C}$ (NRC 2010). Our results suggest that the amenity value of

climate could significantly increase estimates of climate damages, even for moderate temperature increases.

\section{References}

Albouy, D. Y. 2012. Are Big Cities Bad Places to Live? Estimating Quality of Life across Metropolitan Areas. NBER Working Paper 14472. Original 2008, revised May 29, 2012. Cambridge, MA: National Bureau of Economic Research.

Albouy, D., W. Graf, R. Kellogg, and H. Wolff. 2016. Climate Amenities, Climate Change and American Quality of Life. Journal of the Association of Environmental and Resource Economists 3(1): 205-246.

Bartik, T. 1985. Business Location Decisions in the United States: Estimates of the Effects of Unionization, Taxes, and Other Characteristics of States. Journal of Business and Economic Statistics 3(1): 14-22.

Bayer, P., N. Keohane, and C. Timmins. 2009. Migration and Hedonic Valuation: The Case of Air Quality. Journal of Environmental Economics and Management 58: 1-14.

Bayer, P., R. McMillan, and K. Reuben. 2004. An Equilibrium Model of Sorting in an Urban Housing Market. NBER Working Paper 10865. Cambridge, MA: National Bureau of Economic Research.

Bayer, P., and C. Timmins. 2007. Estimating Equilibrium Models of Sorting across Locations. Economic Journal 117 (518): 353-74.

Blomquist, G. C., M. C. Berger, and J. P. Hoehn. 1988. New Estimates of Quality of Life in Urban Areas. American Economic Review 78 (1): 89-107.

Cragg, M., and M. Kahn. 1997. New Estimates of Climate Demand: Evidence from Location Choice. Journal of Urban Economics 42: 261-84.

-1999. Climate Consumption and Climate Pricing from 1940 to 1990. Regional Science and Urban Economics 29:519-39. 
Dahl, G. 2002. Mobility and the Return to Education: Testing a Roy Model with Multiple Markets. Econometrica 70 (6): 2367-3420.

Deschenes, O., and M. Greenstone. 2011. Climate Change, Mortality, and Adaptation: Evidence from Annual Fluctuations in Weather in the US. American Economic Journal: Applied Economics 3 (4): 152-85.

Graves, P., and P. Mueser. 1993. The Role of Equilibrium and Disequilibrium in Modeling Regional Growth and Decline: A Critical Reassessment. Journal of Regional Science 33 (1): 69-84.

Gyourko, J., and J. Tracy. 1991. The Structure of Local Public Finance and the Quality of Life. Journal of Political Economy 99 (4): 774-806.

Hamilton, T and D. Phaneuf. 2015. An integrated model of regional and local residential sorting with application to air quality. Journal of Environmental Economics and Management 74: 71-93.

IPCC (Intergo vernmental Panel on Climate Change). 2000. Special Report: Emissions Scenarios: Summary for Policymakers. A Special Report of IPCC Working Group III. Cambridge, UK: Cambridge University Press.

Kahn, M. 2009. Urban Growth and Climate Change. Annual Review of Resource Economics 1: $333-50$.

Karl, T. R., J. M. Melillo, and T. C. Peterson, eds. 2009. Global Climate Change Impacts in the United States. Cambridge, UK: Cambridge University Press.

Klaiber, H. A., and D. J. Phaneuf. 2010. Valuing Open Space in a Residential Sorting Model of the Twin Cities. Journal of Environmental Economics and Management 60 (2): 57-77.

McFadden, D. 1978. Modeling the Choice of Residential Location. In Spatial Interaction Theory and Planning Models, edited by A. Karlqvist, L. Lundquist, F. Snickars, and J. Weibull. Amsterdam: North Holland.

- 1999. Computing Willingness-to-Pay in Random Utility Models. In Trade, Theory and Econometrics. Essay in Honor of John S. Chipman, edited by J. Melvin, J. Moore, and R. Riezman. London: Routledge.

NRC (National Research Council). 2010. Hidden Costs of Energy: Unpriced Consequences of Energy Production and Use. Washington, DC: National Academies Press.

Rappaport, J. 2007. Moving to Nice Weather. Regional Science and Urban Economics 47 (3): $375-98$.

Roback, J. 1982. Wages, Rents, and the Quality of Life. Journal of Political Economy 90 (6): $1257-78$. 
Savageau, D., and R. D’Agostino. 2000. Places Rated Almanac: Millennium Edition. New York: Hungry Minds.

Schlenker, W., and M. Roberts. 2009. Nonlinear Temperature Effects Indicate Severe Damages to US Crop Yields under Climate Change. Proceedings of the National Academy of Sciences 106 (37): 15594-98.

Sinha, P., and M. Cropper. 2013. The Value of Climate Amenities: Evidence from U.S. Migration Decisions. NBER Working Paper 18756. Cambridge, MA: National Bureau of Economic Research.

Smith, V. K. 1983. The Role of Site and Job Characteristics in Hedonic Wage Models. Journal of Urban Economics 13 (3): 296-321.

von Haefen, R. H. 2003. Incorporating Observed Choice into the Construction of Welfare Measures from Random Utility Models. Journal of Environmental Economics and Management 45: 145-65. 


\section{Figures and Tables}

Figure 1. Taste-Sorting for Winter Temperature by Metropolitan Area (Base Discrete Choice Model: Model 1)

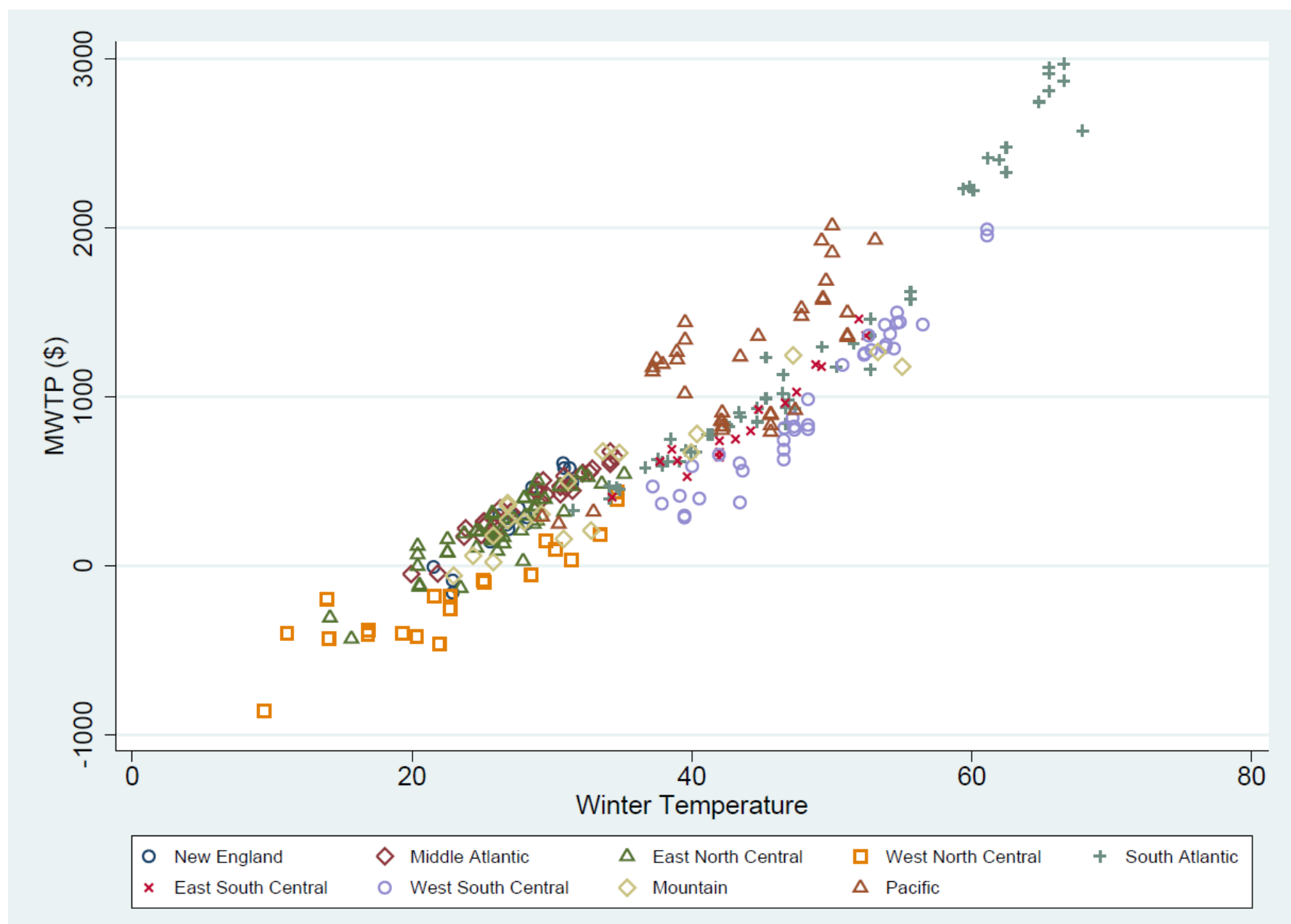




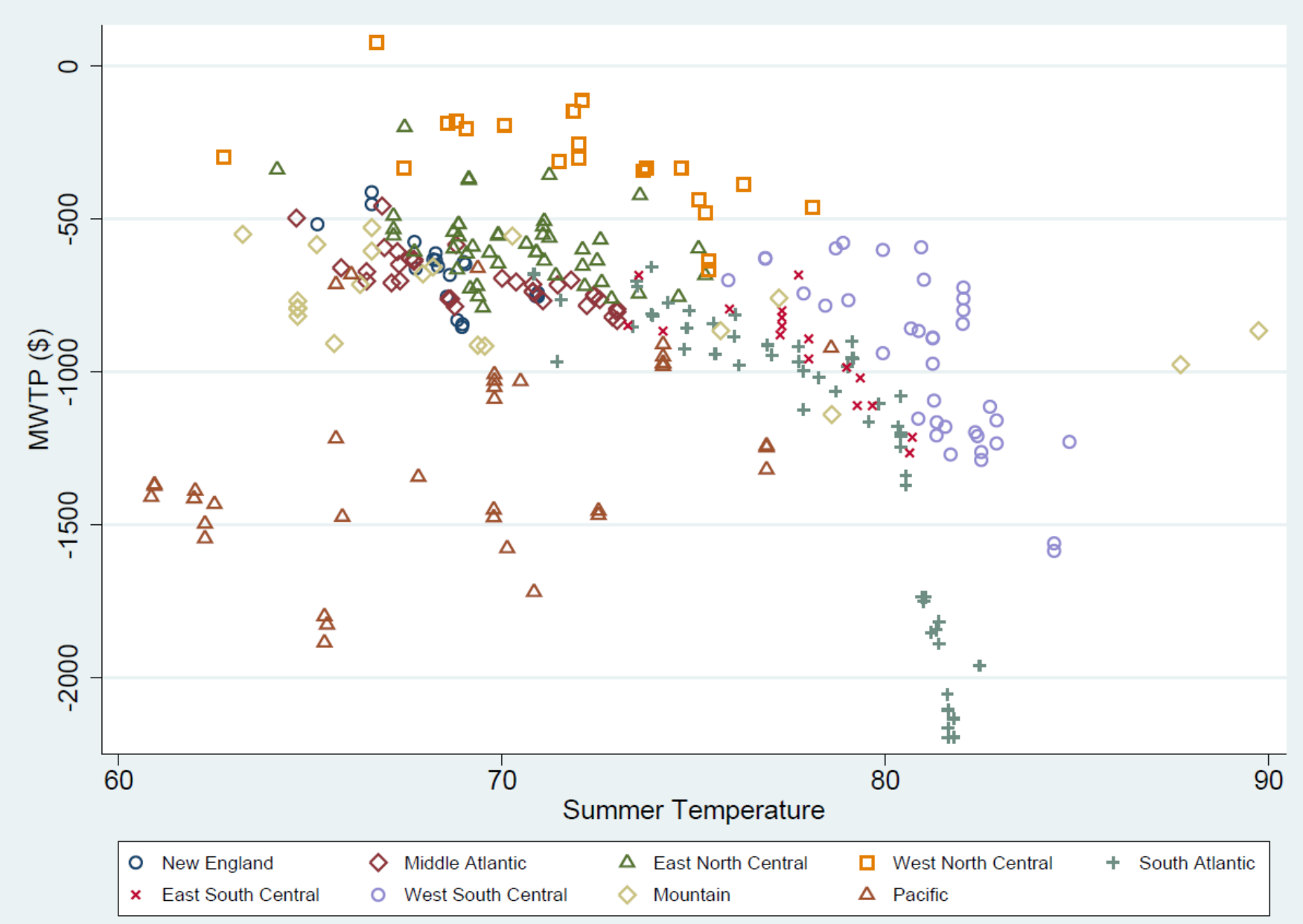

Figure 2. Taste-Sorting for Summer Temperature by Metropolitan Area (Base Discrete Choice Model: Model 1) 
Figure 3. Marginal Willingness to Pay Conditional on Current Location, by Census Division

\section{Panel A}

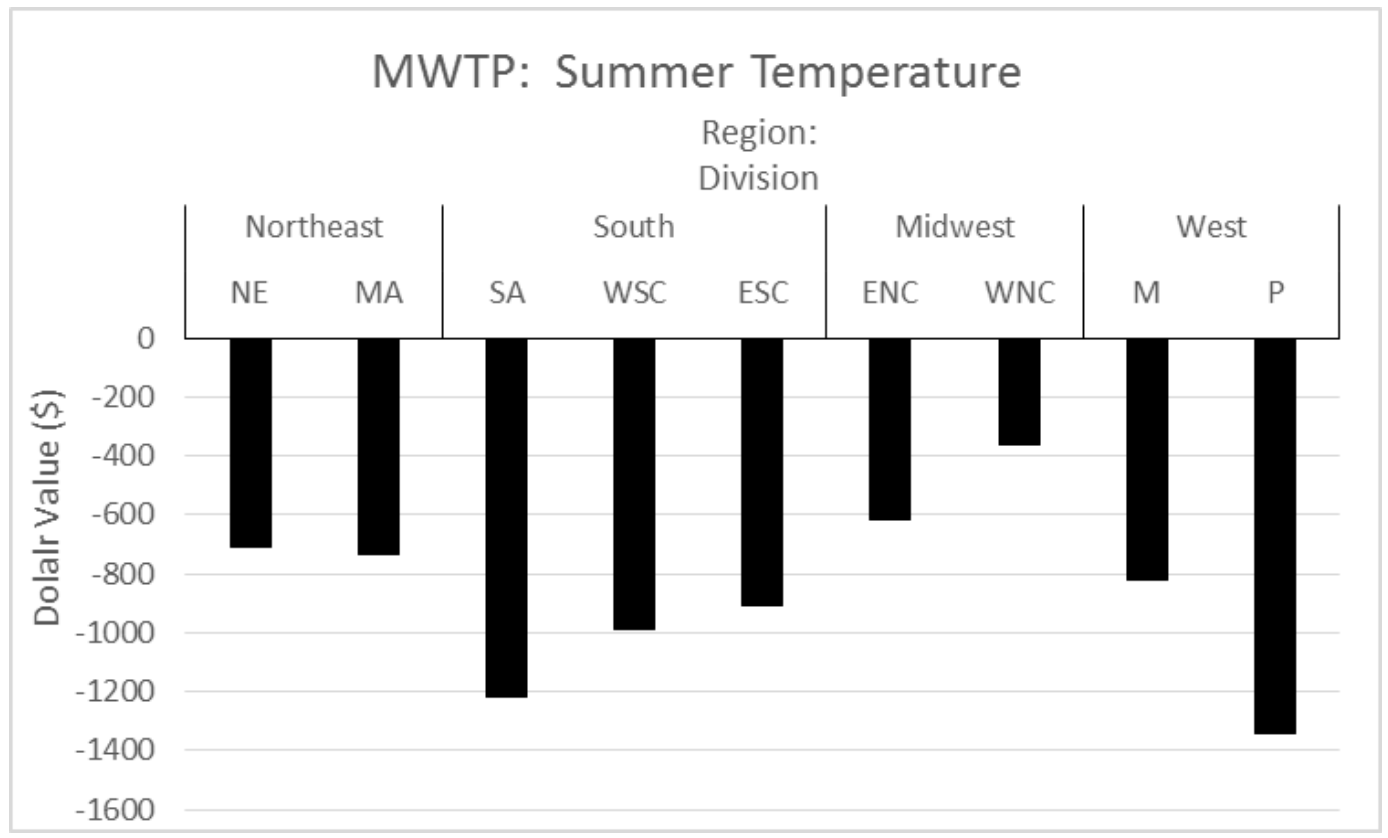

Panel B

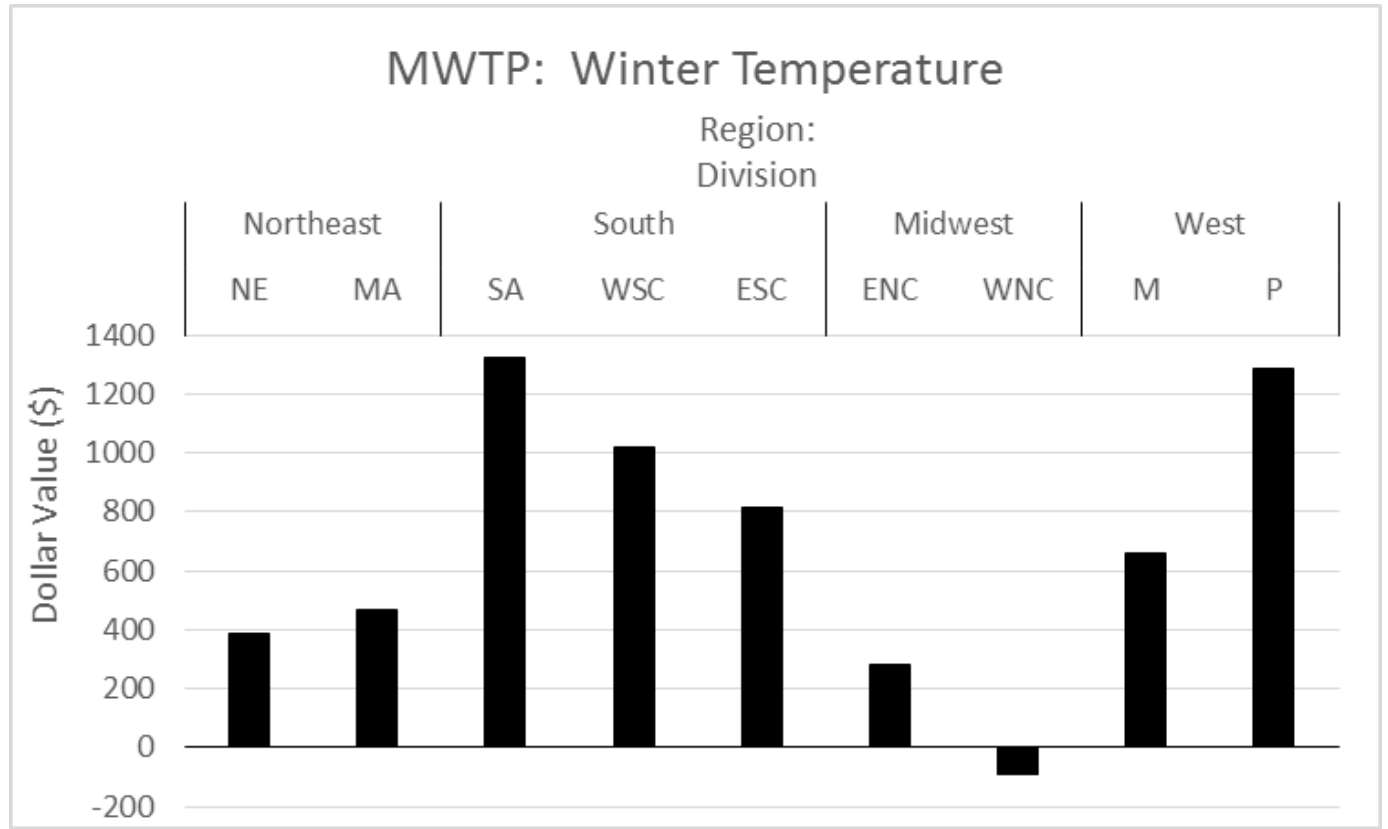


Figure 4. Projected Temperature Changes by Census Division, for SRES Scenarios (2020 to 2050)

Panel A

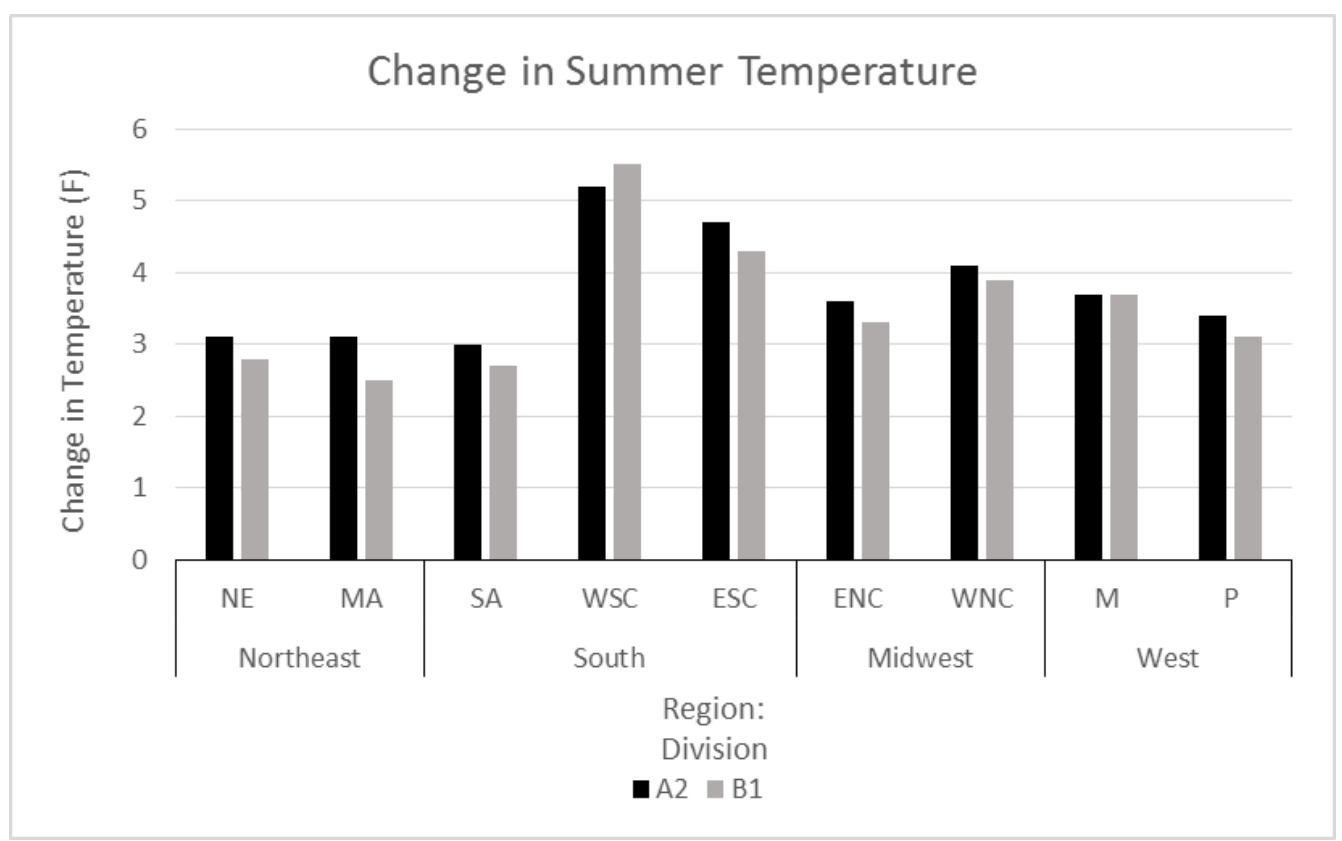

Panel B

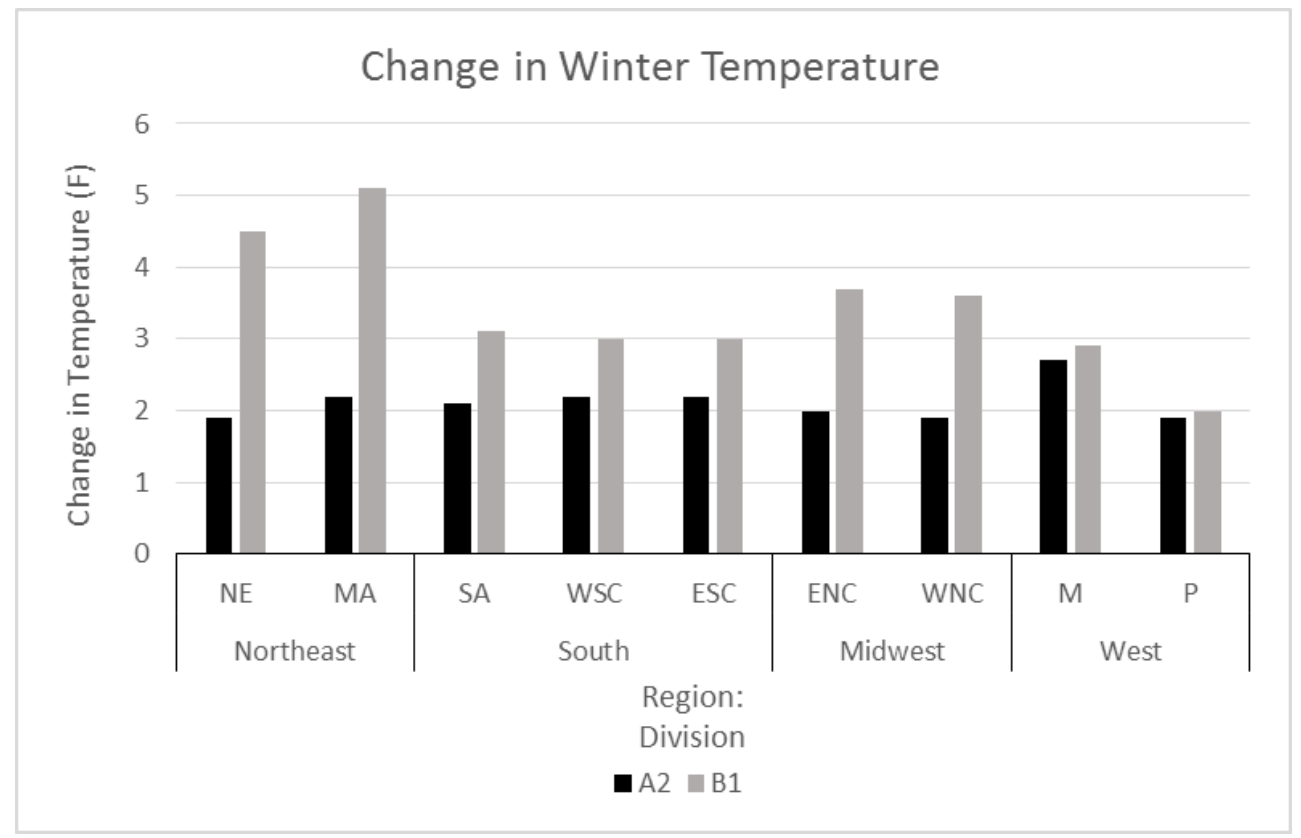


Figure 5. Willingness to Pay Conditional on Current Location by Census Division, for Scenarios A2 and B1

\section{Panel A}

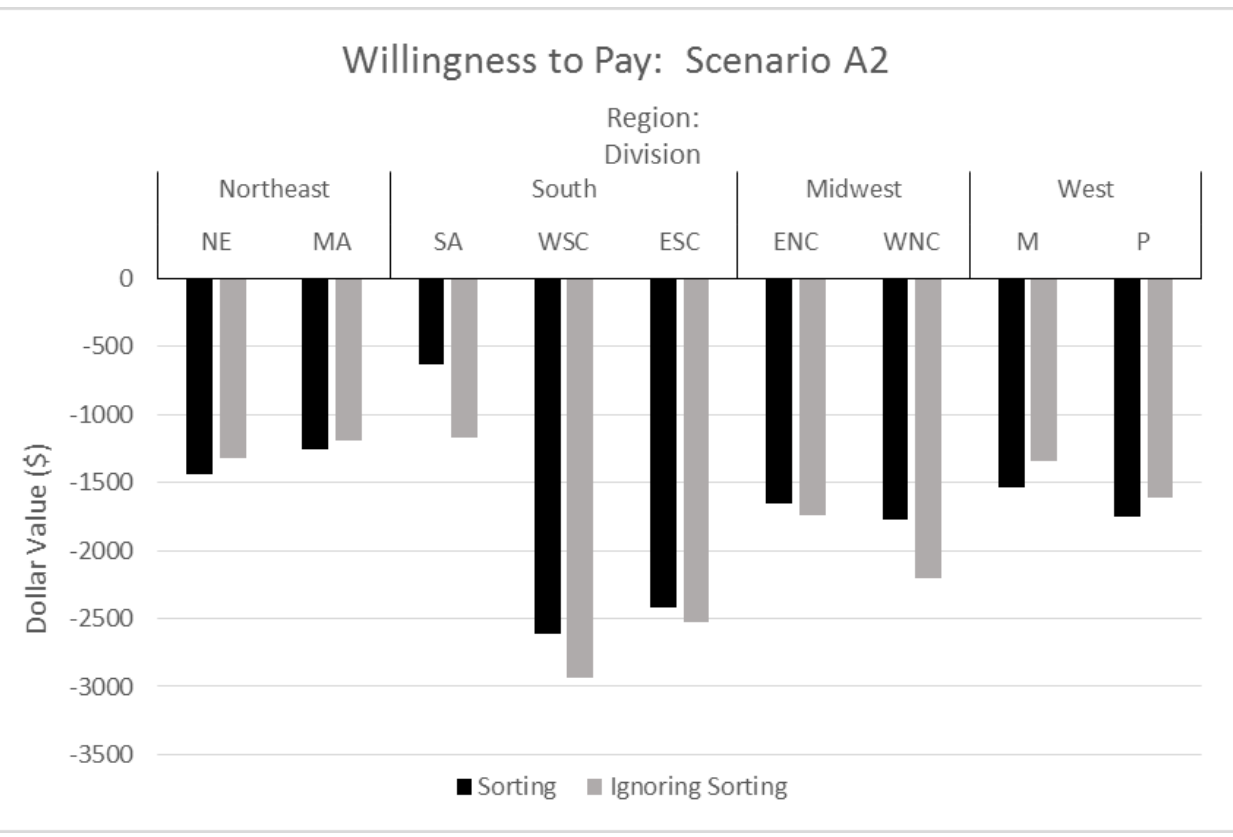

\section{Panel B}

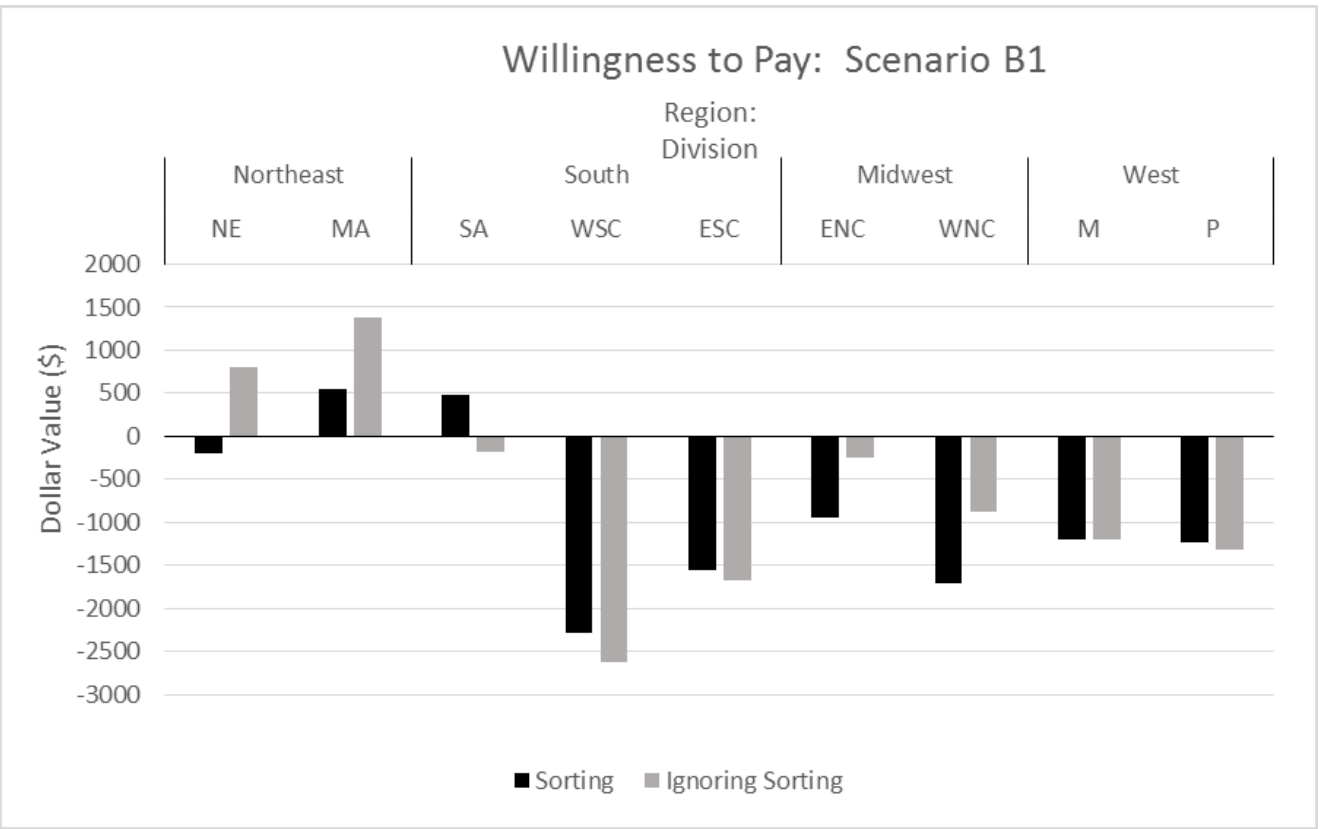


Figure 6. Expected Compensating Variation and Willingness to Pay, Holding Location Constant, for Scenarios A2 and B1

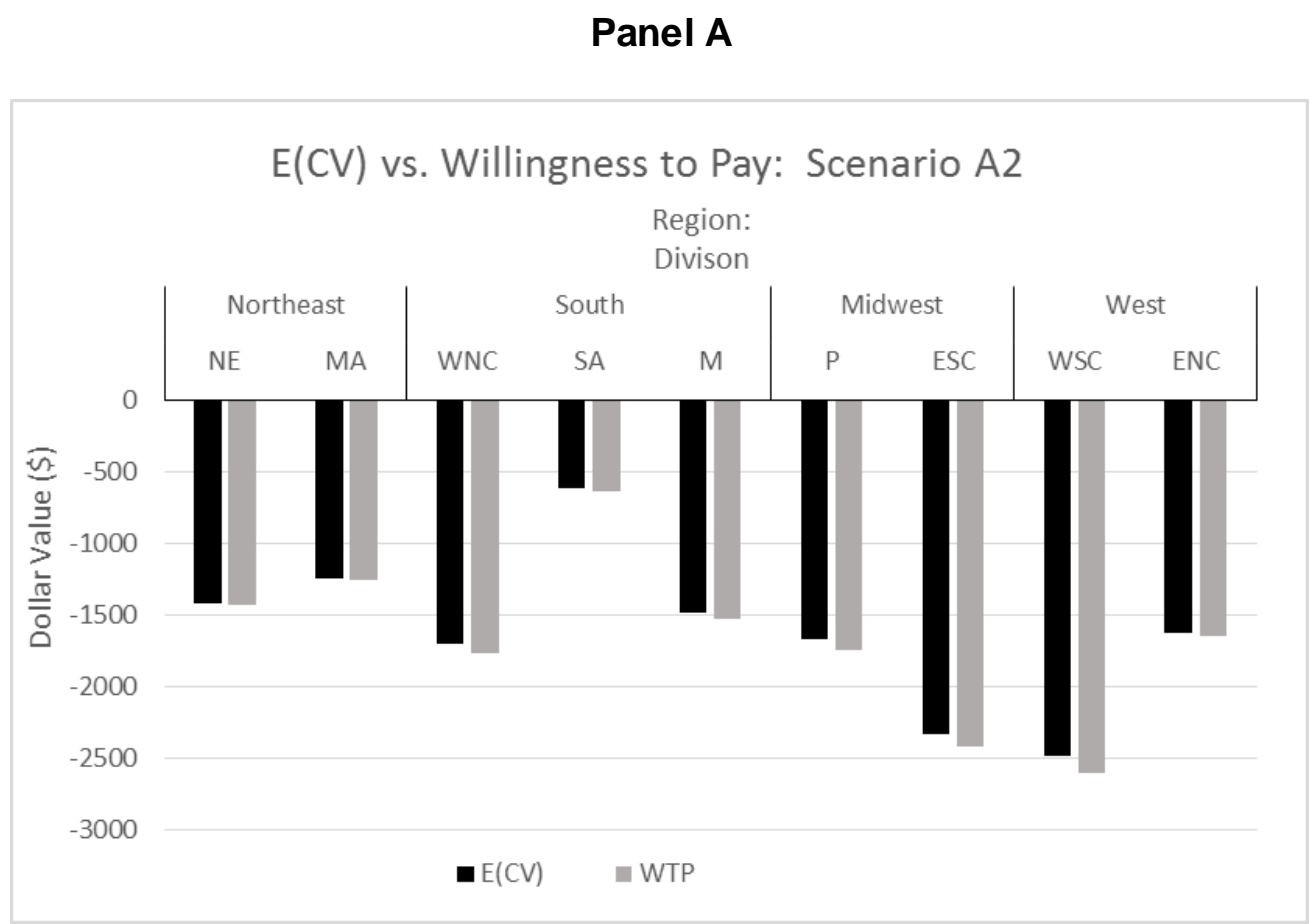

\section{Panel B}

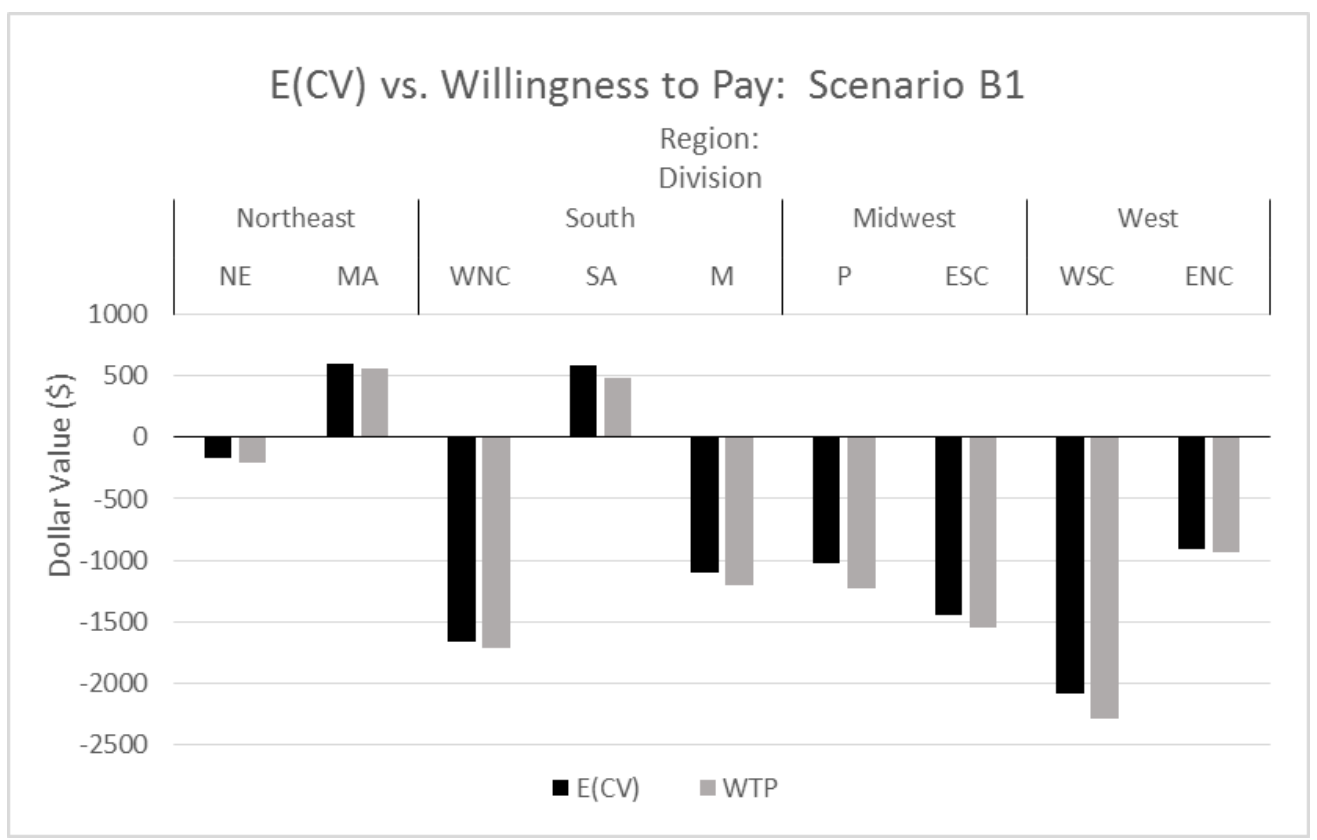


Table 1. Descriptive Statistics for Household Characteristics

\begin{tabular}{|c|c|c|c|c|c|c|c|c|c|}
\hline \multirow[b]{2}{*}{ Variable } & \multirow[b]{2}{*}{ Description } & \multicolumn{2}{|c|}{$\begin{array}{l}\text { Full sample } \\
(N=54,008)\end{array}$} & \multicolumn{2}{|c|}{$\begin{array}{l}\text { Prime-aged } \\
(N=33,180)\end{array}$} & \multicolumn{2}{|c|}{$\begin{array}{l}\text { Greater than } 55 \\
(N=17,643)\end{array}$} & \multicolumn{2}{|c|}{$\begin{array}{c}\text { Movers } \\
(N=22,759)\end{array}$} \\
\hline & & Mean & $\begin{array}{l}\text { Std. } \\
\text { dev. }\end{array}$ & Mean & $\begin{array}{l}\text { Std. } \\
\text { dev. }\end{array}$ & Mean & $\begin{array}{l}\text { Std. } \\
\text { dev. }\end{array}$ & Mean & $\begin{array}{l}\text { Std. } \\
\text { dev. }\end{array}$ \\
\hline $\begin{array}{l}\text { Age of household head } \\
\text { (mean) }\end{array}$ & Age & 49.11 & 17.03 & 40.79 & 8.20 & 69.50 & 9.41 & 39.89 & 15.19 \\
\hline $\begin{array}{l}\text { Gender of household } \\
\text { head }\end{array}$ & Male (\%) & 63.93 & & 67.02 & & 60.60 & & 64.21 & \\
\hline $\begin{array}{l}\text { Marital status of } \\
\text { household head }\end{array}$ & Married (\%) & 52.22 & & 55.43 & & 50.99 & & 46.81 & \\
\hline \multirow{3}{*}{$\begin{array}{l}\text { Race of household } \\
\text { head }\end{array}$} & White (\%) & 82.70 & & 81.13 & & 87.03 & & 83.86 & \\
\hline & Black (\%) & 13.11 & & 13.97 & & 10.98 & & 9.97 & \\
\hline & Other (\%) & 4.20 & & 4.91 & & 1.99 & & 6.16 & \\
\hline \multirow{5}{*}{$\begin{array}{l}\text { Education of } \\
\text { household head }\end{array}$} & No high school (\%) & 12.86 & & 7.56 & & 23.09 & & 5.77 & \\
\hline & High school (\%) & 25.96 & & 24.06 & & 29.71 & & 15.22 & \\
\hline & Some college (\%) & 30.89 & & 33.73 & & 23.65 & & 31.11 & \\
\hline & College graduate $(\%)$ & 19.33 & & 22.67 & & 12.95 & & 31.12 & \\
\hline & Postgraduate education (\%) & 10.96 & & 11.99 & & 10.62 & & 16.78 & \\
\hline Household head & Left state of birth (\%) & 42.65 & & 40.99 & & 47.32 & & 66.69 & \\
\hline \multirow[t]{2}{*}{$\begin{array}{l}\text { Movement from place } \\
\text { of birth }\end{array}$} & $\begin{array}{l}\text { Left census division of birth } \\
\text { (\%) }\end{array}$ & 32.78 & & 31.28 & & 36.86 & & 53.86 & \\
\hline & $\begin{array}{l}\text { Left census region of birth } \\
\text { (\%) }\end{array}$ & 26.55 & & 24.98 & & 30.85 & & 43.68 & \\
\hline $\begin{array}{l}\text { Household wage } \\
\text { earnings (mean) }\end{array}$ & $\begin{array}{l}\text { Sum of the wage eamings of } \\
\text { all household members }\end{array}$ & $\$ 49,960$ & $\$ 54,508$ & $\$ 64,098$ & $\$ 55,106$ & $\$ 26,307$ & $\$ 47,544$ & $\$ 58,208$ & $\$ 60,898$ \\
\hline $\begin{array}{l}\text { Household wage } \\
\text { earnings }\end{array}$ & $\begin{array}{l}\text { Households with zero wage } \\
\text { earnings (\%) }\end{array}$ & 16.75 & & 2.23 & & 46.94 & & 8.83 & \\
\hline
\end{tabular}


Table 1. Descriptive Statistics for Household Characteristics

\begin{tabular}{|c|c|c|c|c|c|c|c|c|c|}
\hline \multirow[b]{2}{*}{ Variable } & \multirow[b]{2}{*}{ Description } & \multicolumn{2}{|c|}{$\begin{array}{l}\text { Full sample } \\
(N=54,008)\end{array}$} & \multicolumn{2}{|c|}{$\begin{array}{l}\text { Prime-aged } \\
(N=33,180)\end{array}$} & \multicolumn{2}{|c|}{$\begin{array}{l}\text { Greater than } 55 \\
(N=17,643)\end{array}$} & \multicolumn{2}{|c|}{ 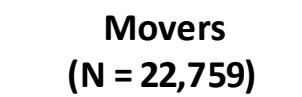 } \\
\hline & & Mean & $\begin{array}{l}\text { Std. } \\
\text { dev. }\end{array}$ & Mean & $\begin{array}{l}\text { Std. } \\
\text { dev. }\end{array}$ & Mean & $\begin{array}{l}\text { Std. } \\
\text { dev. }\end{array}$ & Mean & $\begin{array}{l}\text { Std. } \\
\text { dev. }\end{array}$ \\
\hline $\begin{array}{l}\text { Total household } \\
\text { income (mean) }\end{array}$ & $\begin{array}{l}\text { Sum of wage, business, and } \\
\text { farm incomes and income } \\
\text { from other sources }^{a} \text { of all } \\
\text { household members }\end{array}$ & $\$ 63,312$ & $\$ 58,671$ & $\$ 69,161$ & $\$ 59,723$ & $\$ 57,294$ & $\$ 58,615$ & $\$ 67,532$ & $\$ 65,438$ \\
\hline $\begin{array}{l}\text { Household annual } \\
\text { housing expenditures } \\
\text { (mean) }\end{array}$ & $\begin{array}{l}\text { Sum of monthly mortgage } \\
\text { payment or rent, cost of } \\
\text { utilities, insurance, and } \\
\text { property taxes }\end{array}$ & $\$ 15,556$ & $\$ 9,082$ & $\$ 16,193$ & $\$ 9,437$ & $\$ 15,481$ & $\$ 8,560$ & $\$ 14,693$ & $\$ 9,711$ \\
\hline \multirow[t]{3}{*}{ Size of household } & 1 member (\%) & 26.16 & & 21.05 & & 36.03 & & 29.75 & \\
\hline & 2 members (\%) & 34.69 & & 27.35 & & 47.68 & & 34.87 & \\
\hline & 3 or more members (\%) & 39.15 & & 51.59 & & 16.28 & & 35.38 & \\
\hline
\end{tabular}

${ }^{a}$ Income from other sources would ind ude Social Security income; welfare (public assistance) income; Supplementary Security income; interest, dividend, and rental income; retirement income; and other income. 
Table 2. Descriptive Statistics of Amenity Variables

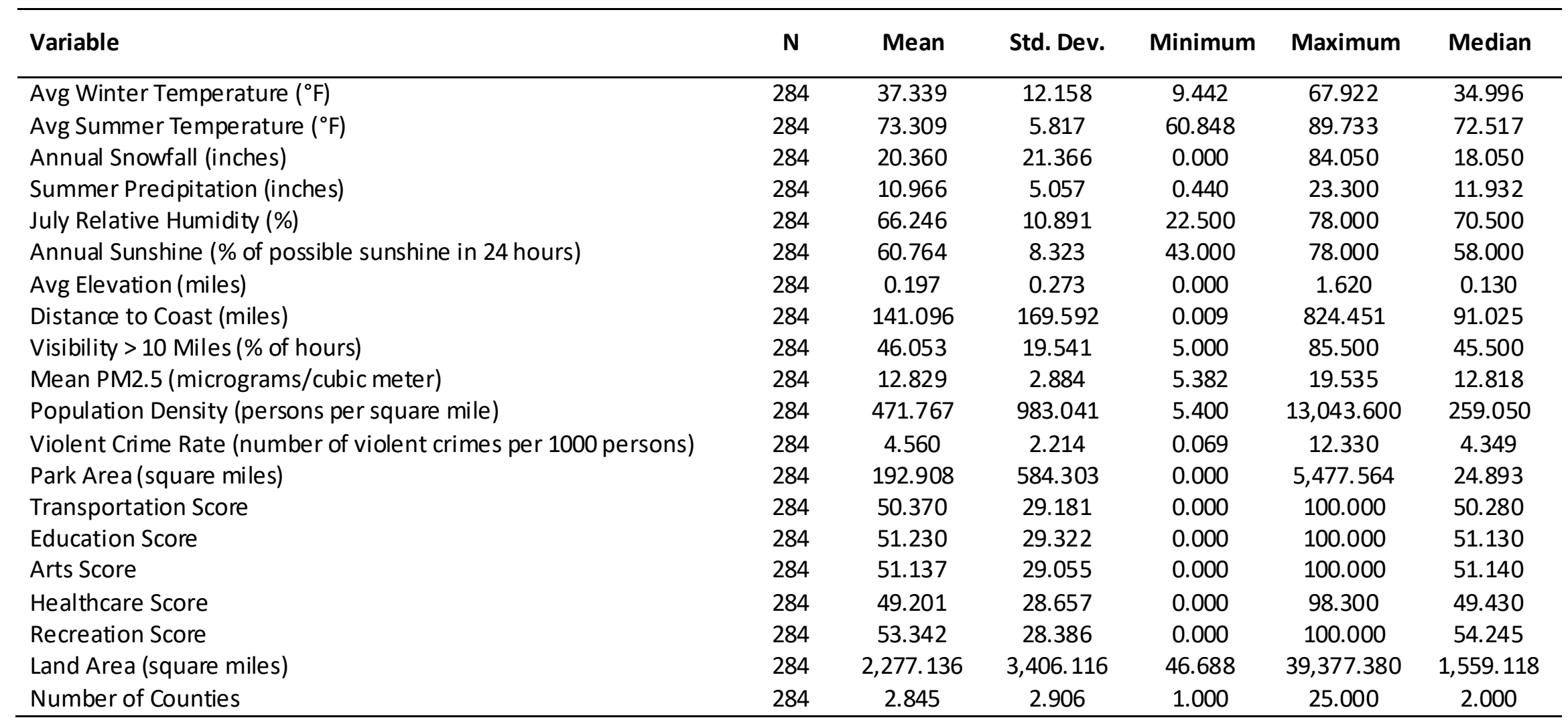


Table 3. Marginal Willingness to Pay for Climate Amenities (Base Discrete Choice Models)

\begin{tabular}{|c|c|c|c|c|}
\hline Sample & $\begin{array}{l}\text { Model } 1 \text { (Full) } \\
\text { All Ages } \\
\text { (Base Model) }\end{array}$ & $\begin{array}{l}\text { Model } 1 \text { (Prime) } \\
\text { Prime-Aged }\end{array}$ & $\begin{array}{l}\text { Model } 1 \text { (>55) } \\
\text { Over } 55 \text { Years }\end{array}$ & $\begin{array}{c}\text { Model } 1 \text { (Movers) } \\
\text { Changed MSA } \\
\text { between } \\
1995 \text { and } 2000\end{array}$ \\
\hline PANEL A: 1st Stage Estimates & & & & \\
\hline Variable & $\begin{array}{c}\text { Coef } \\
\text { (Std Err) }\end{array}$ & $\begin{array}{c}\text { Coef } \\
\text { (Std Err) }\end{array}$ & $\begin{array}{c}\text { Coef } \\
\text { (Std Err) }\end{array}$ & $\begin{array}{c}\text { Coef } \\
\text { (Std Err) }\end{array}$ \\
\hline Std. Dev: Avg Winter Temperature & $\begin{array}{c}0.0666 \\
(0.0020)\end{array}$ & $\begin{array}{c}0.0588 \\
(0.0026)\end{array}$ & $\begin{array}{c}0.0742 \\
(0.0039)\end{array}$ & $\begin{array}{c}0.0781 \\
(0.0038)\end{array}$ \\
\hline Std. Dev: Avg Summer Temperature & $\begin{array}{c}0.0522 \\
(0.0060)\end{array}$ & $\begin{array}{c}0.0592 \\
(0.0068)\end{array}$ & $\begin{array}{c}0.0331 \\
(0.0091)\end{array}$ & $\begin{array}{c}0.0698 \\
(0.0079)\end{array}$ \\
\hline Correlation Coefficient & -0.8332 & -0.6893 & -0.9936 & -0.8245 \\
\hline
\end{tabular}

PANEL B: 2nd Stage Estimates

\begin{tabular}{|c|c|c|c|c|c|c|c|c|}
\hline Variable & $\begin{array}{c}\text { Coef } \\
\text { (Std Err) }\end{array}$ & $\begin{array}{l}\text { MWTP } \\
\text { (Std Err) }\end{array}$ & $\begin{array}{c}\text { Coef } \\
\text { (Std Err) }\end{array}$ & $\begin{array}{l}\text { MWTP } \\
\text { (Std Err) }\end{array}$ & $\begin{array}{c}\text { Coef } \\
\text { (Std Err) }\end{array}$ & $\begin{array}{l}\text { MWTP } \\
\text { (Std Err) }\end{array}$ & $\begin{array}{c}\text { Coef } \\
\text { (Std Err) }\end{array}$ & $\begin{array}{l}\text { MWTP } \\
\text { (Std Err) }\end{array}$ \\
\hline Mean: Avg Winter Temperature & $\begin{array}{c}0.0249 \\
(0.0056)\end{array}$ & $\begin{array}{c}\$ 709 \\
(\$ 160)\end{array}$ & $\begin{array}{c}0.0209 \\
(0.0058)\end{array}$ & $\begin{array}{c}\$ 518 \\
(\$ 144)\end{array}$ & $\begin{array}{c}0.0375 \\
(0.0070)\end{array}$ & $\begin{array}{l}\$ 1,035 \\
(\$ 199)\end{array}$ & $\begin{array}{c}0.0424 \\
(0.0078)\end{array}$ & $\begin{array}{c}\$ 983 \\
(\$ 184)\end{array}$ \\
\hline Mean: Avg Summer Temperature & $\begin{array}{c}-0.0307 \\
(0.0091)\end{array}$ & $\begin{array}{l}-\$ 873 \\
(\$ 260)\end{array}$ & $\begin{array}{r}-0.0253 \\
(0.0100)\end{array}$ & $\begin{array}{l}-\$ 627 \\
(\$ 249)\end{array}$ & $\begin{array}{r}-0.0516 \\
(0.0106)\end{array}$ & $\begin{array}{c}-\$ 1,424 \\
(\$ 301)\end{array}$ & $\begin{array}{c}-0.0478 \\
(0.0121)\end{array}$ & $\begin{array}{c}-\$ 1,109 \\
(\$ 283)\end{array}$ \\
\hline July Humidity & $\begin{array}{r}-0.0269 \\
(0.0049)\end{array}$ & $\begin{array}{l}-\$ 764 \\
(\$ 142)\end{array}$ & $\begin{array}{r}-0.0208 \\
(0.0054)\end{array}$ & $\begin{array}{l}-\$ 514 \\
(\$ 135)\end{array}$ & $\begin{array}{r}-0.0325 \\
(0.0054)\end{array}$ & $\begin{array}{l}-\$ 896 \\
(\$ 155)\end{array}$ & $\begin{array}{l}-0.0316 \\
(0.0059)\end{array}$ & $\begin{array}{l}-\$ 734 \\
(\$ 139)\end{array}$ \\
\hline Annual Snowfall & $\begin{array}{r}-0.0166 \\
(0.0024)\end{array}$ & $\begin{array}{r}-\$ 471 \\
(\$ 70)\end{array}$ & $\begin{array}{r}-0.0170 \\
(0.0026)\end{array}$ & $\begin{array}{r}-\$ 422 \\
(\$ 66)\end{array}$ & $\begin{array}{r}-0.0154 \\
(0.0026)\end{array}$ & $\begin{array}{r}-\$ 425 \\
(\$ 75)\end{array}$ & $\begin{array}{r}-0.0215 \\
(0.0029)\end{array}$ & $\begin{array}{l}-\$ 499 \\
(\$ 69)\end{array}$ \\
\hline Ln(Summer Precipitation) & $\begin{array}{c}0.1408 \\
(0.0720)\end{array}$ & $\begin{array}{c}\$ 376 \\
(\$ 192)\end{array}$ & $\begin{array}{c}0.1708 \\
(0.0768)\end{array}$ & $\begin{array}{c}\$ 403 \\
(\$ 181)\end{array}$ & $\begin{array}{c}0.0926 \\
(0.0823)\end{array}$ & $\begin{array}{c}\$ 232 \\
(\$ 206)\end{array}$ & $\begin{array}{c}0.3279 \\
(0.0890)\end{array}$ & $\begin{array}{c}\$ 741 \\
(\$ 202)\end{array}$ \\
\hline Annual Sunshine & $\begin{array}{r}-0.0155 \\
(0.0057) \\
\end{array}$ & $\begin{array}{l}-\$ 441 \\
(\$ 162)\end{array}$ & $\begin{array}{r}-0.0149 \\
(0.0060) \\
\end{array}$ & $\begin{array}{l}-\$ 368 \\
(\$ 149)\end{array}$ & $\begin{array}{c}-0.0111 \\
(0.0067) \\
\end{array}$ & $\begin{array}{l}-\$ 307 \\
(\$ 185)\end{array}$ & $\begin{array}{c}-0.0127 \\
(0.0076)\end{array}$ & $\begin{array}{l}-\$ 296 \\
(\$ 177)\end{array}$ \\
\hline
\end{tabular}

Note: When entering the regressions non-linearly, amenity variables are evaluated at population-weighted means in order to compute MWTP. Non-linear covariates are the following: population density, summer precipitation, and elevation enter in log form while dista nce to the coast enters the model quadratically. 
Table 4. Marginal Willingness to Pay for Climate Amenities (Sensitivity to Moving Costs)

\begin{tabular}{|c|c|c|c|c|c|c|c|c|}
\hline \multirow{2}{*}{$\begin{array}{l}\text { Sensitivity } \\
\text { PANEL A: 1st Stage Estimates }\end{array}$} & \multicolumn{2}{|c|}{$\begin{array}{c}\text { Model } 1 \\
\text { Base Model }\end{array}$} & \multicolumn{2}{|c|}{$\begin{array}{l}\text { Model } 2 \\
\text { Moving Costs: } \\
\text { Ln(Distance) }\end{array}$} & \multicolumn{2}{|c|}{$\begin{array}{l}\text { Model } 3 \\
\text { Moving Costs: } \\
\text { Married and } \\
\text { Children } \\
\text { Interactions }\end{array}$} & \multicolumn{2}{|c|}{$\begin{array}{l}\text { Model } 4 \\
\text { Moving Costs: } \\
\text { Omitted }\end{array}$} \\
\hline & $\begin{array}{c}\text { Coef } \\
\text { (Std Err) }\end{array}$ & & $\begin{array}{c}\text { Coef } \\
\text { (Std Err) }\end{array}$ & & $\begin{array}{c}\text { Coef } \\
\text { (Std Err) }\end{array}$ & & $\begin{array}{c}\text { Coef } \\
\text { (Std Err) }\end{array}$ & \\
\hline Std. Dev: Avg Winter Temperature & $\begin{array}{c}0.0666 \\
(0.0020)\end{array}$ & & $\begin{array}{c}0.0758 \\
(0.0020)\end{array}$ & & $\begin{array}{c}0.0664 \\
(0.0020)\end{array}$ & & $\begin{array}{c}0.0022 \\
(0.0148)\end{array}$ & \\
\hline Std. Dev: Avg Summer Temperature & $\begin{array}{c}0.0522 \\
(0.0060)\end{array}$ & & $\begin{array}{c}0.0717 \\
(0.0049)\end{array}$ & & $\begin{array}{c}0.0525 \\
(0.0059)\end{array}$ & & $\begin{array}{c}0.0210 \\
(0.0278)\end{array}$ & \\
\hline $\begin{array}{l}\text { Correlation Coefficient } \\
\text { PANEL B: 2nd Stage Estimates }\end{array}$ & -0.8332 & & -0.8263 & & -0.8295 & & -0.9975 & \\
\hline Variable & $\begin{array}{c}\text { Coef } \\
\text { (Std Err) }\end{array}$ & $\begin{array}{c}\text { MWTP } \\
\text { (Std Err) }\end{array}$ & $\begin{array}{c}\text { Coef } \\
\text { (Std Err) }\end{array}$ & $\begin{array}{c}\text { MWTP } \\
\text { (Std Err) }\end{array}$ & $\begin{array}{c}\text { Coef } \\
\text { (Std Err) }\end{array}$ & $\begin{array}{c}\text { MWTP } \\
\text { (Std Err) }\end{array}$ & $\begin{array}{c}\text { Coef } \\
\text { (Std Err) }\end{array}$ & $\begin{array}{l}\text { MWTP } \\
\text { (Std Err) }\end{array}$ \\
\hline Mean: Avg Winter Temperature & $\begin{array}{c}0.0249 \\
(0.0056)\end{array}$ & $\begin{array}{c}\$ 709 \\
(\$ 160)\end{array}$ & $\begin{array}{c}0.0278 \\
(0.0056)\end{array}$ & $\begin{array}{c}\$ 790 \\
(\$ 162)\end{array}$ & $\begin{array}{c}0.0248 \\
(0.0056)\end{array}$ & $\begin{array}{c}\$ 704 \\
\text { (\$159) }\end{array}$ & $\begin{array}{c}0.0232 \\
(0.0054)\end{array}$ & $\begin{array}{c}\$ 659 \\
(\$ 154)\end{array}$ \\
\hline Mean: Avg Summer Temperature & $\begin{array}{l}-0.0307 \\
(0.0091)\end{array}$ & $\begin{array}{l}-\$ 873 \\
(\$ 260)\end{array}$ & $\begin{array}{l}-0.0319 \\
(0.0095)\end{array}$ & $\begin{array}{l}-\$ 907 \\
(\$ 269)\end{array}$ & $\begin{array}{l}-0.0308 \\
(0.0091)\end{array}$ & $\begin{array}{l}-\$ 872 \\
(\$ 259)\end{array}$ & $\begin{array}{l}-0.0169 \\
(0.0090)\end{array}$ & $\begin{array}{r}-\$ 478 \\
(\$ 255)\end{array}$ \\
\hline July Humidity & $\begin{array}{l}-0.0269 \\
(0.0049)\end{array}$ & $\begin{array}{l}-\$ 764 \\
(\$ 142)\end{array}$ & $\begin{array}{l}-0.0285 \\
(0.0050)\end{array}$ & $\begin{array}{l}-\$ 809 \\
(\$ 145)\end{array}$ & $\begin{array}{l}-0.0268 \\
(0.0049)\end{array}$ & $\begin{array}{l}-\$ 758 \\
(\$ 141)\end{array}$ & $\begin{array}{l}-0.0189 \\
(0.0044)\end{array}$ & $\begin{array}{l}-\$ 535 \\
(\$ 125)\end{array}$ \\
\hline Annual Snowfall & $\begin{array}{l}-0.0166 \\
(0.0024)\end{array}$ & $\begin{array}{l}-\$ 471 \\
(\$ 70)\end{array}$ & $\begin{array}{l}-0.0165 \\
(0.0024)\end{array}$ & $\begin{array}{l}-\$ 468 \\
(\$ 70)\end{array}$ & $\begin{array}{l}-0.0165 \\
(0.0024)\end{array}$ & $\begin{array}{l}-\$ 467 \\
(\$ 69)\end{array}$ & $\begin{array}{l}-0.0038 \\
(0.0023)\end{array}$ & $\begin{array}{l}-\$ 109 \\
(\$ 66)\end{array}$ \\
\hline Ln(Summer Precipitation) & $\begin{array}{c}0.1408 \\
(0.0720)\end{array}$ & $\begin{array}{c}\$ 376 \\
(\$ 192)\end{array}$ & $\begin{array}{c}0.0953 \\
(0.0739)\end{array}$ & $\begin{array}{c}\$ 254 \\
(\$ 197)\end{array}$ & $\begin{array}{c}0.1426 \\
(0.0720)\end{array}$ & $\begin{array}{c}\$ 379 \\
(\$ 192)\end{array}$ & $\begin{array}{c}0.0922 \\
(0.0666)\end{array}$ & $\begin{array}{c}\$ 245 \\
(\$ 177)\end{array}$ \\
\hline Annual Sunshine & $\begin{array}{l}-0.0155 \\
(0.0057)\end{array}$ & $\begin{array}{c}-\$ 441 \\
(\$ 162)\end{array}$ & $\begin{array}{l}-0.0170 \\
(0.0059)\end{array}$ & $\begin{array}{r}-\$ 482 \\
(\$ 168)\end{array}$ & $\begin{array}{c}-0.0153 \\
(0.0057)\end{array}$ & $\begin{array}{r}-\$ 434 \\
(\$ 162)\end{array}$ & $\begin{array}{c}-0.0100 \\
(0.0057)\end{array}$ & $\begin{array}{l}-\$ 284 \\
(\$ 161)\end{array}$ \\
\hline
\end{tabular}

Note: When entering the regressions non-linearly, amenity variables are evaluated at population-weighted means in order to compute

MWTP. Non-linear covariates are the following: population density, summer precipitation, and elevation enter in log form while distance to the coast enters the model quadratically. 
Table 5. Marginal Willingness to Pay for Climate Amenities (Sensitivity to Second Stage Specifications)

\begin{tabular}{|c|c|c|c|c|c|c|c|c|c|c|}
\hline Sensitivity & \multicolumn{2}{|c|}{$\begin{array}{c}\text { Model } 1 \\
\text { Base Model }\end{array}$} & \multicolumn{2}{|c|}{$\begin{array}{c}\text { Model } 5 \\
\text { Omit } \\
\text { Ln(Population } \\
\text { Density) }\end{array}$} & \multicolumn{2}{|c|}{$\begin{array}{c}\text { Model } 6 \\
\text { Ln(land area) } \\
\text { replaces } \\
\text { Ln(population } \\
\text { density) }\end{array}$} & \multicolumn{2}{|c|}{$\begin{array}{c}\text { Model } 7 \\
\text { Include number of } \\
\text { counties }\end{array}$} & \multicolumn{2}{|c|}{$\begin{array}{c}\text { Model } 8 \\
\text { Omit Other } \\
\text { Climate Variables }\end{array}$} \\
\hline Variable & $\begin{array}{c}\text { Coef } \\
\text { (Std Err) } \\
\end{array}$ & $\begin{array}{c}\text { MWTP } \\
\text { (Std Err) }\end{array}$ & $\begin{array}{c}\text { Coef } \\
\text { (Std Err) } \\
\end{array}$ & $\begin{array}{l}\text { MWTP } \\
\text { (Std Err) }\end{array}$ & $\begin{array}{c}\text { Coef } \\
\text { (Std Err) }\end{array}$ & $\begin{array}{l}\text { MWTP } \\
\text { (Std Err) }\end{array}$ & $\begin{array}{c}\text { Coef } \\
\text { (Std Err) }\end{array}$ & $\begin{array}{l}\text { MWTP } \\
\text { (Std Err) }\end{array}$ & $\begin{array}{c}\text { Coef } \\
\text { (Std Err) }\end{array}$ & $\begin{array}{l}\text { MWTP } \\
\text { (Std Err) }\end{array}$ \\
\hline Mean: Avg Winter Temperature & $\begin{array}{c}0.0249 \\
(0.0056)\end{array}$ & $\begin{array}{c}\$ 709 \\
(\$ 160)\end{array}$ & $\begin{array}{c}0.0263 \\
(0.0059)\end{array}$ & $\begin{array}{c}\$ 748 \\
(\$ 169)\end{array}$ & $\begin{array}{c}0.0255 \\
(0.0060)\end{array}$ & $\begin{array}{c}\$ 725 \\
(\$ 171)\end{array}$ & $\begin{array}{c}0.0287 \\
(0.0050)\end{array}$ & $\begin{array}{c}\$ 815 \\
(\$ 142)\end{array}$ & $\begin{array}{c}0.0435 \\
(0.0047)\end{array}$ & $\begin{array}{l}\$ 1,237 \\
(\$ 139)\end{array}$ \\
\hline $\begin{array}{l}\text { Mean: Avg Summer } \\
\text { Temperature }\end{array}$ & $\begin{array}{l}-0.0307 \\
(0.0091)\end{array}$ & $\begin{array}{l}-\$ 873 \\
(\$ 260)\end{array}$ & $\begin{array}{l}-0.0299 \\
(0.0100)\end{array}$ & $\begin{array}{l}-\$ 849 \\
(\$ 285)\end{array}$ & $\begin{array}{l}-0.0313 \\
(0.0103)\end{array}$ & $\begin{array}{l}-\$ 890 \\
(\$ 293)\end{array}$ & $\begin{array}{l}-0.0298 \\
(0.0091)\end{array}$ & $\begin{array}{l}-\$ 848 \\
(\$ 259)\end{array}$ & $\begin{array}{l}-0.0288 \\
(0.0110)\end{array}$ & $\begin{array}{l}-\$ 820 \\
(\$ 313)\end{array}$ \\
\hline July Humidity & $\begin{array}{c}-0.0269 \\
(0.0049)\end{array}$ & $\begin{array}{l}-\$ 764 \\
(\$ 142)\end{array}$ & $\begin{array}{l}-0.0247 \\
(0.0055)\end{array}$ & $\begin{array}{l}-\$ 702 \\
(\$ 157)\end{array}$ & $\begin{array}{l}-0.0219 \\
(0.0058)\end{array}$ & $\begin{array}{l}-\$ 623 \\
(\$ 166)\end{array}$ & $\begin{array}{l}-0.0246 \\
(0.0047)\end{array}$ & $\begin{array}{l}-\$ 700 \\
(\$ 135)\end{array}$ & & \\
\hline Annual Snowfall & $\begin{array}{l}-0.0166 \\
(0.0024)\end{array}$ & $\begin{array}{r}-\$ 471 \\
(\$ 70)\end{array}$ & $\begin{array}{l}-0.0152 \\
(0.0026)\end{array}$ & $\begin{array}{r}-\$ 434 \\
(\$ 75)\end{array}$ & $\begin{array}{l}-0.0142 \\
(0.0027)\end{array}$ & $\begin{array}{l}-\$ 404 \\
(\$ 77)\end{array}$ & $\begin{array}{l}-0.0134 \\
(0.0023)\end{array}$ & $\begin{array}{l}-\$ 381 \\
(\$ 65)\end{array}$ & & \\
\hline Ln(Summer Precipitation) & $\begin{array}{c}0.1408 \\
(0.0720)\end{array}$ & $\begin{array}{c}\$ 376 \\
(\$ 192)\end{array}$ & $\begin{array}{c}0.0969 \\
(0.0769)\end{array}$ & $\begin{array}{c}\$ 258 \\
(\$ 205)\end{array}$ & $\begin{array}{c}0.0925 \\
(0.0792)\end{array}$ & $\begin{array}{c}\$ 247 \\
(\$ 211)\end{array}$ & $\begin{array}{c}0.0751 \\
(0.0710)\end{array}$ & $\begin{array}{c}\$ 200 \\
(\$ 189)\end{array}$ & & \\
\hline Annual Sunshine & $\begin{array}{l}-0.0155 \\
(0.0057)\end{array}$ & $\begin{array}{l}-\$ 441 \\
(\$ 162)\end{array}$ & $\begin{array}{l}-0.0190 \\
(0.0059)\end{array}$ & $\begin{array}{l}-\$ 540 \\
(\$ 168)\end{array}$ & $\begin{array}{l}-0.0184 \\
(0.0060)\end{array}$ & $\begin{array}{l}-\$ 524 \\
(\$ 170)\end{array}$ & $\begin{array}{l}-0.0147 \\
(0.0057)\end{array}$ & $\begin{array}{l}-\$ 417 \\
(\$ 163)\end{array}$ & & \\
\hline
\end{tabular}

Notes:

(1) As these sensitivities only involve changing 2 nd stage variables, only estimates from stage 2 are reported.

(2) When entering the regressions non-linearly, amenity variables are evaluated at population-weighted means in order to compute MWTP. Non-linear covariates are the following: population density, summer precipitation, and elevation enter in log form while distance to the coast enters the model quadratically. 
Table 6. Temperature, Temperature Changes, and Willingness to Pay Conditional on Current Location, by Census Division

\begin{tabular}{|c|c|c|c|c|c|c|c|c|c|c|}
\hline \multirow{2}{*}{$\begin{array}{l}\text { Census region } \\
\text { Census division }\end{array}$} & \multicolumn{2}{|c|}{ Northeast } & \multicolumn{3}{|c|}{ South } & \multicolumn{2}{|c|}{ Midwest } & \multicolumn{2}{|c|}{ West } & \multirow{2}{*}{$\begin{array}{l}\text { All } \\
\text { All }\end{array}$} \\
\hline & NE & MA & SA & WSC & ESC & ENC & WNC & $\mathbf{M}$ & $\mathbf{P}$ & \\
\hline \multicolumn{11}{|c|}{ PANEL A: Baseline Values (1970 to 2000) } \\
\hline Share of population & $5 \%$ & $15 \%$ & $19 \%$ & $11 \%$ & $3 \%$ & $17 \%$ & $4 \%$ & $6 \%$ & $19 \%$ & $46 \%$ \\
\hline ST & 69 & 71 & 78 & 81 & 77 & 71 & 71 & 74 & 71 & 74 \\
\hline WT & 28 & 30 & 48 & 49 & 43 & 27 & 22 & 37 & 47 & 39 \\
\hline MWTP for ST & (711) & $(737)$ & $(1215)$ & (989) & (910) & $(617)$ & $(363)$ & $(820)$ & (1343) & (940) \\
\hline MWTP for WT & 388 & 466 & 1324 & 1017 & 813 & 279 & (93) & 661 & 1288 & 819 \\
\hline \multicolumn{11}{|c|}{ PANEL B: Projected Values under SRES Scenarios (2020 to 2050) } \\
\hline Change in ST (A2) & 3.1 & 3.1 & 3.0 & 5.2 & 4.7 & 3.6 & 4.1 & 3.7 & 3.4 & 3.6 \\
\hline Change in WT (A2) & 1.9 & 2.2 & 2.1 & 2.2 & 2.2 & 2.0 & 1.9 & 2.7 & 1.9 & 2.1 \\
\hline Change in ST (B1) & 2.8 & 2.5 & 2.7 & 5.5 & 4.3 & 3.3 & 3.9 & 3.7 & 3.1 & 3.3 \\
\hline Change in WT (B1) & 4.5 & 5.1 & 3.1 & 3.0 & 3.0 & 3.7 & 3.6 & 2.9 & 2.0 & 3.4 \\
\hline WTP (A2): based on sorting & (1435) & (1259) & (637) & $(2610)$ & (2421) & (1652) & (1770) & (1534) & $(1750)$ & $(1541)$ \\
\hline WTP (B1): based on sorting & (202) & 552 & 485 & $(2281)$ & (1547) & (936) & (1713) & (1203) & (1231) & (682) \\
\hline WTP (A2): ignoring sorting & (1318) & (1196) & $(1172)$ & (2941) & (2531) & (1737) & (2201) & (1348) & (1611) & $(1662)$ \\
\hline WTP (B1): ignoring sorting & 802 & 1385 & (173) & $(2630)$ & (1667) & $(251)$ & $(868)$ & (1196) & (1315) & (529) \\
\hline
\end{tabular}

Notes: MWTP for ST and WTa re calculated for ea ch household using coefficient dis tributions from Model 1, conditi onal on MSA choice. Values a re a ve ra ged a cross all households in an MSA to obtain the a verage MSA MWTP. WTP is calcula ted by multiplying MSA MWTP by the relevant te mpe ra ture change. All division level va riables a re MSA values weighted by MSA popula tion. NE = New England; MA = Middle Atlantic; SA = South Atlantic; WSC = West South Central; ESC $=$ East South Central; ENC = East North Central; WNC $=$ West North Central; $M=$ Mountain; $P=$ Pacific 
Table 7. Temperature, Temperature Changes, and Willingness to Pay Conditional on Current Location, by Census Region

\begin{tabular}{|c|c|c|c|c|c|}
\hline & Northeast & South & Midwest & West & All \\
\hline \multicolumn{6}{|c|}{ PANEL A: Baseline Values (1970 to 2000) } \\
\hline Share of population & $20 \%$ & $33 \%$ & $22 \%$ & $25 \%$ & $100 \%$ \\
\hline ST & 70 & 79 & 71 & 72 & 74 \\
\hline WT & 30 & 48 & 26 & 45 & 39 \\
\hline MWTP for ST & $(730)$ & $(1108)$ & (567) & $(1213)$ & (940) \\
\hline MWTP for WT & 447 & 1170 & 206 & 1192 & 819 \\
\hline
\end{tabular}

\section{PANEL B: Projected Values under SRES Scenarios (2020 to 2050)}

\begin{tabular}{|c|c|c|c|c|c|}
\hline Change in ST (A2) & 3.1 & 3.9 & 3.7 & 3.5 & 3.6 \\
\hline Change in WT (A2) & 2.1 & 2.1 & 1.9 & 2.1 & 2.1 \\
\hline Change in ST (B1) & 2.6 & 3.8 & 3.4 & 3.3 & 3.3 \\
\hline Change in WT (B1) & 4.9 & 3.1 & 3.7 & 2.2 & 3.4 \\
\hline WTP (A2): based on sorting & $(1302)$ & $(1485)$ & $(1675)$ & (1697) & $(1541)$ \\
\hline WTP (B1): based on sorting & 368 & $(660)$ & (1089) & $(1224)$ & (682) \\
\hline WTP (A2): ignoring sorting & $(1226)$ & (1910) & $(1828)$ & $(1546)$ & $(1662)$ \\
\hline WTP (B1): ignoring sorting & 1243 & (1161) & (372) & (1285) & (529) \\
\hline
\end{tabular}

Notes: MWTP for ST and WTa re calculated for ea ch household using coefficient dis tributions from Model 1, conditional on MSA choice. Values a re ave raged a cross all

households in an MSA to obtain the average MSA MWTP. WTP is calcula ted by multiplying MSA MWTP by the relevant te mperature change. All region-level va riables a re MSA values weighted by MSA population. 
Table 8. Expected Compensating Variation and Willingness to Pay, Holding Location Constant, for Scenarios A2 and B1

\begin{tabular}{|c|c|c|c|c|c|c|c|c|c|c|}
\hline \multirow{2}{*}{$\begin{array}{l}\text { Census region } \\
\text { Census division } \\
\end{array}$} & \multicolumn{2}{|c|}{ Northeast } & \multicolumn{3}{|c|}{ South } & \multicolumn{2}{|c|}{ Midwest } & \multicolumn{2}{|c|}{ West } & \multirow{2}{*}{ All } \\
\hline & NE & MA & SA & WSC & ESC & ENC & WNC & $\mathbf{M}$ & $\mathbf{P}$ & \\
\hline$E(C V)$ scenario $A 2$ & (1423) & (1245) & (613) & (2485) & (2338) & (1623) & (1705) & (1491) & (1673) & (1492) \\
\hline$E(C V)$ scenario B1 & $(171)$ & 602 & 589 & (2083) & (1447) & (904) & (1665) & (1098) & $(1020)$ & (574) \\
\hline WTP scenario A2 & (1435) & (1259) & (637) & (2610) & $(2421)$ & $(1652)$ & (1770) & (1534) & $(1750)$ & (1541) \\
\hline WTP scenario B1 & $(202)$ & 552 & 485 & (2281) & (1547) & (936) & (1713) & (1203) & (1231) & (682) \\
\hline
\end{tabular}

Notes: $E(C V$ is calcula ted as des cribed in the text for each household. Values a re a veraged over all households in an MSA, a nd MSA a verages a re weighted by popula tion to yield division a vera ges. MWTP for ST and WT a re calculated for each household using coefficient dis tributions from Model 1 , conditional on MSA choice. Values a re a veraged across all households in an MSA to obtain the a ve ra ge MSA MWTP. WTP is calcula ted by mul tiplying MSA MWTP by the relevant te mpera ture change. All di vision-level va riables a re MSA values weighte d by MSA population. $\mathrm{NE}=\mathrm{New}$ England; $\mathrm{MA}=$ Middle Atlantic; $\mathrm{SA}=$ South Atlantic; WSC $=$ West South Central $; \mathrm{ESC}=\mathrm{East}$ South Central; $\mathrm{ENC}=$ East North Central; WNC $=$ West North Central $; M=$ Mountain; $P=$ Pa cific 


\section{Appendix A}

Table A-1. Summary of Hedonic Wage Coefficients

\begin{tabular}{|c|c|c|}
\hline $\begin{array}{l}\text { Variables } \\
\text { (Dependent Variable: log(wage rate)) }\end{array}$ & $\begin{array}{l}\text { Mean of Estimates } \\
\text { from } 284 \text { MSAs }\end{array}$ & $\begin{array}{l}\text { Std Dev of Estimates } \\
\text { from } 284 \text { MSAs }\end{array}$ \\
\hline High School (left out category is no high school) & 0.098 & 0.038 \\
\hline Some College & 0.180 & 0.045 \\
\hline College Graduate & 0.382 & 0.069 \\
\hline Higher Education & 0.546 & 0.074 \\
\hline Age & 0.048 & 0.007 \\
\hline Age squared (divided by 100 ) & 0.000 & 0.000 \\
\hline Married & 0.092 & 0.021 \\
\hline Male & 0.215 & 0.040 \\
\hline Black (left out category is white) & -0.070 & 0.070 \\
\hline Other Race & -0.055 & 0.054 \\
\hline Speaks English Well & 0.126 & 0.103 \\
\hline Hispanic & -0.057 & 0.074 \\
\hline $\begin{array}{l}\text { Business Operations Occupation (left out category is } \\
\text { Management Occupation) }\end{array}$ & -0.122 & 0.067 \\
\hline Financial Specialists Occupation & -0.116 & 0.072 \\
\hline Computer and Math Occupation & 0.004 & 0.089 \\
\hline Engineering Occupation & -0.073 & 0.083 \\
\hline Life, Physical, \& Social Sciences Occupation & -0.180 & 0.100 \\
\hline Social Services Occupation & -0.328 & 0.078 \\
\hline Legal Occupation & -0.039 & 0.127 \\
\hline Teachers Occupation & -0.190 & 0.093 \\
\hline Other Educational Occupation & -0.473 & 0.129 \\
\hline Arts, Sports \& Media Occupation & -0.243 & 0.094 \\
\hline Healthcare Practitioners Occupation & 0.062 & 0.078 \\
\hline Healthcare Support Occupation & -0.330 & 0.078 \\
\hline Protective Services Occupation & -0.240 & 0.106 \\
\hline Food and Serving Occupation & -0.428 & 0.077 \\
\hline Maintenance Occupation & -0.472 & 0.074 \\
\hline Personal Care Service Occupation & -0.423 & 0.114 \\
\hline High Skill Sales Occupation & -0.136 & 0.067 \\
\hline Low Skill Sales Occupation & -0.228 & 0.062 \\
\hline Office Support Occupation & -0.298 & 0.049 \\
\hline Construction Trades \& Extraction Workers Occupation & -0.246 & 0.090 \\
\hline Maintenance Workers Occupation & -0.192 & 0.065 \\
\hline Production Occupation & -0.317 & 0.084 \\
\hline Transportation Occupation & -0.357 & 0.075 \\
\hline
\end{tabular}


Table A-1. Summary of Hedonic Wage Coefficients

\begin{tabular}{lcc}
\hline $\begin{array}{l}\text { Variables } \\
\text { (Dependent Variable: log(wage rate)) }\end{array}$ & $\begin{array}{c}\text { Mean of Estimates } \\
\text { from 284 MSAs }\end{array}$ & $\begin{array}{c}\text { Std Dev of Estimates } \\
\text { from 284 MSAs }\end{array}$ \\
\hline $\begin{array}{l}\text { Construction Industry (left out category is Mining and } \\
\text { Utilities) }^{\text {a }}\end{array}$ & -0.180 & 0.095 \\
Manufacturing Industry & & 0.107 \\
Wholesale Industry & -0.120 & 0.097 \\
Retail Industry & -0.185 & 0.094 \\
Transportation Industry & -0.339 & 0.107 \\
Information \& Communications Industry & -0.084 & 0.109 \\
Finance Industry & -0.134 & 0.105 \\
Professional and Scientific Management Services & -0.175 & 0.101 \\
Industry & -0.220 & \\
Educational and Health Social Services Industry & & 0.092 \\
Recreation and Food Services Industry & -0.267 & 0.110 \\
Other Services Industry & -0.370 & 0.101 \\
Public Administration Industry & -0.343 & 0.095 \\
\hline
\end{tabular}

${ }^{a}$ Since these two industries have a very low number of observations, we bundled them together as the omitted category 


\section{Table A-2. Summary of Hedonic Housing Coefficients}

\begin{tabular}{|c|c|c|}
\hline $\begin{array}{l}\text { Variables } \\
\text { (Dependent Variable: log(user costs including } \\
\text { insurance and utility costs)) }\end{array}$ & $\begin{array}{l}\text { Mean of Estimates } \\
\text { from } 284 \mathrm{MSAs}\end{array}$ & $\begin{array}{l}\text { Std Dev of Estimates } \\
\text { from } 284 \text { MSAs }\end{array}$ \\
\hline House is Owned & 0.464 & 0.144 \\
\hline $\begin{array}{l}3 \text { Bedrooms (left out category is less than three } \\
\text { bedrooms) }\end{array}$ & 0.160 & 0.061 \\
\hline 4 Bedrooms & 0.208 & 0.082 \\
\hline 5 Bedrooms & 0.324 & 0.110 \\
\hline Greater than 5 Bedrooms & 0.500 & 0.163 \\
\hline $\begin{array}{l}2 \text { Rooms (left out category is less than two } \\
\text { rooms) }\end{array}$ & 0.080 & 0.133 \\
\hline 3 Rooms & 0.053 & 0.140 \\
\hline 4 Rooms & 0.075 & 0.146 \\
\hline 5 Rooms & 0.126 & 0.154 \\
\hline 6 Rooms & 0.218 & 0.156 \\
\hline Greater than 6 Rooms & 0.413 & 0.176 \\
\hline Complete Kitchen & -0.104 & 0.261 \\
\hline Complete Plumbing & 0.221 & 0.212 \\
\hline 1 to 10 Acres & 0.246 & 0.140 \\
\hline $\begin{array}{l}0 \text { to } 1 \text { years old (left out category is over } 61 \\
\text { years old) }\end{array}$ & 0.428 & 0.157 \\
\hline 2 to 5 years old & 0.404 & 0.158 \\
\hline 6 to 10 years old & 0.358 & 0.150 \\
\hline 11 to 20 years old & 0.247 & 0.127 \\
\hline 21 to 30 years old & 0.150 & 0.122 \\
\hline 31 to 40 years old & 0.093 & 0.113 \\
\hline 41 to 50 years old & 0.039 & 0.089 \\
\hline 51 to 60 years old & -0.011 & 0.075 \\
\hline $\begin{array}{l}\text { Number of Units in Structure: Single-Attached } \\
\text { (left out category is single family detached) }\end{array}$ & -0.082 & 0.105 \\
\hline 2 Units in Structure & -0.089 & 0.107 \\
\hline 3 to 4 Units in Structure & -0.135 & 0.095 \\
\hline 5 to 9 Units in Structure & -0.167 & 0.106 \\
\hline 10 to 19 Units in Structure & -0.132 & 0.127 \\
\hline 20 to 49 Units in Structure & -0.154 & 0.151 \\
\hline Over 50 Units in Structure & -0.190 & 0.207 \\
\hline
\end{tabular}


Table A-3. Marg inal Willingness to Pay for All Location-Specific Amen ities (Base Discrete Choice Models)

\begin{tabular}{|c|c|c|c|c|c|c|c|c|}
\hline $\begin{array}{l}\text { Sample } \\
\text { PANEL A: 1st Stage Estimates }\end{array}$ & \multicolumn{2}{|c|}{$\begin{array}{l}\text { Model } 1 \text { (Full) } \\
\text { All Ages } \\
\text { (Base Model) }\end{array}$} & \multicolumn{2}{|c|}{$\begin{array}{l}\text { Model } 1 \text { (Prime) } \\
\text { Prime-Aged }\end{array}$} & \multicolumn{2}{|c|}{$\begin{array}{l}\text { Model } \mathbf{1}(>\mathbf{5 5}) \\
\text { Over } 55 \text { Years }\end{array}$} & \multicolumn{2}{|c|}{$\begin{array}{l}\text { Model } 1 \text { (Movers) } \\
\text { Changed MSA } \\
\text { between } \\
1995 \text { and } 2000\end{array}$} \\
\hline Variable & $\begin{array}{c}\text { Coef } \\
\text { (Std Err) }\end{array}$ & & $\begin{array}{c}\text { Coef } \\
\text { (Std Err) }\end{array}$ & & $\begin{array}{c}\text { Coef } \\
\text { (Std Err) }\end{array}$ & & $\begin{array}{c}\text { Coef } \\
\text { (Std Err) }\end{array}$ & \\
\hline Std. Dev: Avg Winter Temperature & $\begin{array}{c}0.0666 \\
(0.0020)\end{array}$ & & $\begin{array}{c}0.0588 \\
(0.0026)\end{array}$ & & $\begin{array}{c}0.0742 \\
(0.0039)\end{array}$ & & $\begin{array}{c}0.0781 \\
(0.0038)\end{array}$ & \\
\hline Std. Dev: Avg Summer Temperature & $\begin{array}{c}0.0522 \\
(0.0060)\end{array}$ & & $\begin{array}{c}0.0592 \\
(0.0068)\end{array}$ & & $\begin{array}{c}0.0331 \\
(0.0091)\end{array}$ & & $\begin{array}{c}0.0698 \\
(0.0079)\end{array}$ & \\
\hline $\begin{array}{l}\text { Correlation Coefficient } \\
\text { PANEL B: 2nd Stage Estimates }\end{array}$ & -0.8332 & & -0.6893 & & -0.9936 & & -0.8245 & \\
\hline Variable & $\begin{array}{c}\text { Coef } \\
\text { (Std Err) }\end{array}$ & $\begin{array}{c}\text { MWTP } \\
\text { (Std Err) }\end{array}$ & $\begin{array}{c}\text { Coef } \\
\text { (Std Err) }\end{array}$ & $\begin{array}{l}\text { MWTP } \\
\text { (Std Err) }\end{array}$ & $\begin{array}{c}\text { Coef } \\
\text { (Std Err) }\end{array}$ & $\begin{array}{l}\text { MWTP } \\
\text { (Std Err) }\end{array}$ & $\begin{array}{c}\text { Coef } \\
\text { (Std Err) }\end{array}$ & $\begin{array}{l}\text { MWTP } \\
\text { (Std Err) }\end{array}$ \\
\hline Mean: Avg Winter Temperature & $\begin{array}{c}0.0249 \\
(0.0056)\end{array}$ & $\begin{array}{c}\$ 709 \\
(\$ 160)\end{array}$ & $\begin{array}{c}0.0209 \\
(0.0058)\end{array}$ & $\begin{array}{c}\$ 518 \\
(\$ 144)\end{array}$ & $\begin{array}{c}0.0375 \\
(0.0070)\end{array}$ & $\begin{array}{l}\$ 1,035 \\
(\$ 199)\end{array}$ & $\begin{array}{c}0.0424 \\
(0.0078)\end{array}$ & $\begin{array}{c}\$ 983 \\
(\$ 184)\end{array}$ \\
\hline Mean: Avg Summer Temperature & $\begin{array}{l}-0.0307 \\
(0.0091)\end{array}$ & $\begin{array}{l}-\$ 873 \\
(\$ 260)\end{array}$ & $\begin{array}{l}-0.0253 \\
(0.0100)\end{array}$ & $\begin{array}{l}-\$ 627 \\
(\$ 249)\end{array}$ & $\begin{array}{l}-0.0516 \\
(0.0106)\end{array}$ & $\begin{array}{l}-\$ 1,424 \\
(\$ 301)\end{array}$ & $\begin{array}{l}-0.0478 \\
(0.0121)\end{array}$ & $\begin{array}{l}-\$ 1,109 \\
(\$ 283)\end{array}$ \\
\hline July Humidity & $\begin{array}{l}-0.0269 \\
(0.0049)\end{array}$ & $\begin{array}{l}-\$ 764 \\
(\$ 142)\end{array}$ & $\begin{array}{l}-0.0208 \\
(0.0054)\end{array}$ & $\begin{array}{l}-\$ 514 \\
(\$ 135)\end{array}$ & $\begin{array}{l}-0.0325 \\
(0.0054)\end{array}$ & $\begin{array}{l}-\$ 896 \\
(\$ 155)\end{array}$ & $\begin{array}{l}-0.0316 \\
(0.0059)\end{array}$ & $\begin{array}{l}-\$ 734 \\
(\$ 139)\end{array}$ \\
\hline Annual Snowfall & $\begin{array}{l}-0.0166 \\
(0.0024)\end{array}$ & $\begin{array}{l}-\$ 471 \\
(\$ 70)\end{array}$ & $\begin{array}{l}-0.0170 \\
(0.0026)\end{array}$ & $\begin{array}{l}-\$ 422 \\
(\$ 66)\end{array}$ & $\begin{array}{l}-0.0154 \\
(0.0026)\end{array}$ & $\begin{array}{l}-\$ 425 \\
(\$ 75)\end{array}$ & $\begin{array}{l}-0.0215 \\
(0.0029)\end{array}$ & $\begin{array}{l}-\$ 499 \\
(\$ 69)\end{array}$ \\
\hline Ln(Summer Precipitation) & $\begin{array}{c}0.1408 \\
(0.0720)\end{array}$ & $\begin{array}{c}\$ 376 \\
(\$ 192)\end{array}$ & $\begin{array}{c}0.1708 \\
(0.0768)\end{array}$ & $\begin{array}{c}\$ 403 \\
(\$ 181)\end{array}$ & $\begin{array}{c}0.0926 \\
(0.0823)\end{array}$ & $\begin{array}{c}\$ 232 \\
(\$ 206)\end{array}$ & $\begin{array}{c}0.3279 \\
(0.0890)\end{array}$ & $\begin{array}{c}\$ 741 \\
(\$ 202)\end{array}$ \\
\hline Annual Sunshine & $\begin{array}{c}-0.0155 \\
(0.0057)\end{array}$ & $\begin{array}{l}-\$ 441 \\
(\$ 162)\end{array}$ & $\begin{array}{c}-0.0149 \\
(0.0060)\end{array}$ & $\begin{array}{l}-\$ 368 \\
(\$ 149)\end{array}$ & $\begin{array}{r}-0.0111 \\
(0.0067)\end{array}$ & $\begin{array}{l}-\$ 307 \\
(\$ 185)\end{array}$ & $\begin{array}{c}-0.0127 \\
(0.0076)\end{array}$ & $\begin{array}{l}-\$ 296 \\
(\$ 177)\end{array}$ \\
\hline Ln(Population Density) & $\begin{array}{c}0.2283 \\
(0.0452)\end{array}$ & $\begin{array}{c}\$ 7 \\
(\$ 1)\end{array}$ & $\begin{array}{c}0.2094 \\
(0.0494)\end{array}$ & $\begin{array}{c}\$ 6 \\
(\$ 1)\end{array}$ & $\begin{array}{c}0.2939 \\
(0.0521)\end{array}$ & $\begin{array}{c}\$ 9 \\
(\$ 2)\end{array}$ & $\begin{array}{c}0.2535 \\
(0.0592)\end{array}$ & $\begin{array}{l}\$ 6 \\
(\$ 2)\end{array}$ \\
\hline
\end{tabular}


Table A-3. Marg inal Willingness to Pay for All Location-Specific Amen ities (Base Discrete Choice Models)

\begin{tabular}{|c|c|c|c|c|c|c|c|c|}
\hline \multirow{2}{*}{$\begin{array}{l}\text { Sample } \\
\text { Mean PM2.5 }\end{array}$} & \multicolumn{2}{|c|}{$\begin{array}{l}\text { Model } 1 \text { (Full) } \\
\text { All Ages } \\
\text { (Base Model) }\end{array}$} & \multicolumn{2}{|c|}{$\begin{array}{l}\text { Model } 1 \text { (Prime) } \\
\text { Prime-Aged }\end{array}$} & \multicolumn{2}{|c|}{$\begin{array}{l}\text { Model } 1 \text { (>55) } \\
\text { Over } 55 \text { Years }\end{array}$} & \multicolumn{2}{|c|}{$\begin{array}{c}\text { Model } 1 \text { (Movers) } \\
\text { Changed MSA } \\
\text { between } \\
1995 \text { and } 2000\end{array}$} \\
\hline & $\begin{array}{c}0.0708 \\
(0.0159)\end{array}$ & $\begin{array}{l}\$ 2,014 \\
(\$ 455)\end{array}$ & $\begin{array}{c}0.0572 \\
(0.0164)\end{array}$ & $\begin{array}{l}\$ 1,416 \\
(\$ 408)\end{array}$ & $\begin{array}{c}0.0990 \\
(0.0182)\end{array}$ & $\begin{array}{l}\$ 2,731 \\
(\$ 519)\end{array}$ & $\begin{array}{c}0.0767 \\
(0.0202)\end{array}$ & $\begin{array}{l}\$ 1,779 \\
(\$ 471)\end{array}$ \\
\hline Violent Crime Rate & $\begin{array}{c}0.0045 \\
(0.0136)\end{array}$ & $\begin{array}{c}\$ 129 \\
(\$ 386)\end{array}$ & $\begin{array}{c}0.0006 \\
(0.0142)\end{array}$ & $\begin{array}{c}\$ 15 \\
(\$ 352)\end{array}$ & $\begin{array}{c}0.0115 \\
(0.0166)\end{array}$ & $\begin{array}{c}\$ 316 \\
(\$ 458)\end{array}$ & $\begin{array}{l}-0.0090 \\
(0.0173)\end{array}$ & $\begin{array}{l}-\$ 208 \\
(\$ 402)\end{array}$ \\
\hline Transportation Score & $\begin{array}{c}0.0093 \\
(0.0015)\end{array}$ & $\begin{array}{l}\$ 263 \\
(\$ 42)\end{array}$ & $\begin{array}{c}0.0105 \\
(0.0015)\end{array}$ & $\begin{array}{l}\$ 259 \\
(\$ 39)\end{array}$ & $\begin{array}{c}0.0081 \\
(0.0018)\end{array}$ & $\begin{array}{l}\$ 223 \\
(\$ 51)\end{array}$ & $\begin{array}{c}0.0038 \\
(0.0018)\end{array}$ & $\begin{array}{c}\$ 88 \\
(\$ 42)\end{array}$ \\
\hline Education Score & $\begin{array}{c}0.0034 \\
(0.0015)\end{array}$ & $\begin{array}{c}\$ 97 \\
(\$ 44)\end{array}$ & $\begin{array}{c}0.0043 \\
(0.0016)\end{array}$ & $\begin{array}{l}\$ 106 \\
(\$ 41)\end{array}$ & $\begin{array}{c}0.0011 \\
(0.0017)\end{array}$ & $\begin{array}{c}\$ 29 \\
(\$ 48)\end{array}$ & $\begin{array}{c}0.0053 \\
(0.0018)\end{array}$ & $\begin{array}{l}\$ 123 \\
(\$ 41)\end{array}$ \\
\hline Arts Score & $\begin{array}{c}0.0048 \\
(0.0017)\end{array}$ & $\begin{array}{l}\$ 136 \\
(\$ 49)\end{array}$ & $\begin{array}{c}0.0043 \\
(0.0018)\end{array}$ & $\begin{array}{l}\$ 106 \\
(\$ 46)\end{array}$ & $\begin{array}{c}0.0048 \\
(0.0020)\end{array}$ & $\begin{array}{l}\$ 132 \\
(\$ 55)\end{array}$ & $\begin{array}{c}0.0034 \\
(0.0021)\end{array}$ & $\begin{array}{c}\$ 79 \\
(\$ 50)\end{array}$ \\
\hline Healthcare Score & $\begin{array}{c}0.0005 \\
(0.0012)\end{array}$ & $\begin{array}{c}\$ 13 \\
(\$ 33)\end{array}$ & $\begin{array}{c}0.0002 \\
(0.0012)\end{array}$ & $\begin{array}{c}\$ 4 \\
(\$ 31)\end{array}$ & $\begin{array}{c}0.0004 \\
(0.0014)\end{array}$ & $\begin{array}{c}\$ 11 \\
(\$ 39)\end{array}$ & $\begin{array}{c}0.0016 \\
(0.0015)\end{array}$ & $\begin{array}{c}\$ 37 \\
(\$ 34)\end{array}$ \\
\hline Recreation Score & $\begin{array}{c}0.0131 \\
(0.0015)\end{array}$ & $\begin{array}{l}\$ 374 \\
(\$ 44)\end{array}$ & $\begin{array}{c}0.0124 \\
(0.0016)\end{array}$ & $\begin{array}{l}\$ 307 \\
(\$ 41)\end{array}$ & $\begin{array}{c}0.0150 \\
(0.0018)\end{array}$ & $\begin{array}{l}\$ 414 \\
(\$ 54)\end{array}$ & $\begin{array}{c}0.0156 \\
(0.0019)\end{array}$ & $\begin{array}{l}\$ 363 \\
(\$ 46)\end{array}$ \\
\hline Park Area & $\begin{array}{c}0.0002 \\
(0.0001)\end{array}$ & $\begin{array}{c}\$ 4 \\
(\$ 2)\end{array}$ & $\begin{array}{c}0.0001 \\
(0.0001)\end{array}$ & $\begin{array}{c}\$ 4 \\
(\$ 1)\end{array}$ & $\begin{array}{c}0.0002 \\
(0.0001)\end{array}$ & $\begin{array}{l}\$ 5 \\
(\$ 2)\end{array}$ & $\begin{array}{c}0.0002 \\
(0.0001)\end{array}$ & $\begin{array}{l}\$ 4 \\
(\$ 2)\end{array}$ \\
\hline Visibility > 10 Miles & $\begin{array}{c}0.0078 \\
(0.0032)\end{array}$ & $\begin{array}{l}\$ 222 \\
(\$ 92)\end{array}$ & $\begin{array}{c}0.0073 \\
(0.0033)\end{array}$ & $\begin{array}{l}\$ 180 \\
(\$ 82)\end{array}$ & $\begin{array}{c}0.0094 \\
(0.0038)\end{array}$ & $\begin{array}{r}\$ 259 \\
(\$ 106)\end{array}$ & $\begin{array}{c}0.0093 \\
(0.0037)\end{array}$ & $\begin{array}{l}\$ 216 \\
(\$ 87)\end{array}$ \\
\hline Ln(Elevation) & $\begin{array}{c}0.0810 \\
(0.0441)\end{array}$ & $\begin{array}{l}\$ 13,069 \\
(\$ 7,126)\end{array}$ & $\begin{array}{c}0.0895 \\
(0.0481)\end{array}$ & $\begin{array}{l}\$ 12,450 \\
(\$ 6,706)\end{array}$ & $\begin{array}{c}0.0873 \\
(0.0475)\end{array}$ & $\begin{array}{l}\$ 14,273 \\
(\$ 7,798)\end{array}$ & $\begin{array}{c}0.1468 \\
(0.0547)\end{array}$ & $\begin{array}{l}\$ 17,898 \\
(\$ 6,683)\end{array}$ \\
\hline Distance to Coast & $\begin{array}{l}-0.0025 \\
(0.0007)\end{array}$ & $\begin{array}{l}-\$ 45 \\
(\$ 15)\end{array}$ & $\begin{array}{r}-0.0020 \\
(0.0007)\end{array}$ & $\begin{array}{l}-\$ 25 \\
(\$ 14)\end{array}$ & $\begin{array}{l}-0.0035 \\
(0.0008)\end{array}$ & $\begin{array}{l}-\$ 65 \\
(\$ 18)\end{array}$ & $\begin{array}{c}-0.0034 \\
(0.0009)\end{array}$ & $\begin{array}{l}-\$ 52 \\
(\$ 15)\end{array}$ \\
\hline (Distance to Coast)^2 & $\begin{array}{c}0.0000 \\
(0.0000)\end{array}$ & & $\begin{array}{c}0.0000 \\
(0.0000)\end{array}$ & & $\begin{array}{c}0.0000 \\
(0.0000)\end{array}$ & & $\begin{array}{c}0.0000 \\
(0.0000)\end{array}$ & \\
\hline Num. of Obs. (MSAs) & 284 & & 284 & & 284 & & 284 & \\
\hline Adjusted R-squared & 0.84 & & 0.82 & & 0.82 & & 0.78 & \\
\hline
\end{tabular}

Note: When entering the regressions non-linearly, amenity variables are evaluated at population-weighted means in order to compute MWTP. Non-linear covariates are the following: population density, summer precipitation, and elevation enter in log form while distance to the coast enters the model quadratically. 
Table A-4. Marginal Willingness to Pay for Climate Amenities (Sensitivity to HB Specifications)

\begin{tabular}{|c|c|c|c|c|c|c|}
\hline $\begin{array}{l}\text { Sensitivity } \\
\text { PANEL A: 1st Stage Estimates }\end{array}$ & \multicolumn{2}{|c|}{$\begin{array}{c}\text { Model } 1 \\
\text { Base Model }\end{array}$} & \multicolumn{2}{|c|}{$\begin{array}{c}\text { Model } 9 \\
\text { Quadratic HB }\end{array}$} & \multicolumn{2}{|c|}{$\begin{array}{c}\text { Model } 10 \\
\text { Log(Wage) in 1st stage } \\
\text { with housing price index } \\
\text { in } 2 n d \text { stage }\end{array}$} \\
\hline Variable & $\begin{array}{c}\text { Coef } \\
\text { (Std Err) }\end{array}$ & & $\begin{array}{c}\text { Coef } \\
\text { (Std Err) }\end{array}$ & & $\begin{array}{c}\text { Coef } \\
\text { (Std Err) }\end{array}$ & \\
\hline Std. Dev: Avg Winter Temperature & $\begin{array}{c}0.0666 \\
(0.0020)\end{array}$ & & $\begin{array}{c}0.0664 \\
(0.0020)\end{array}$ & & $\begin{array}{c}0.0673 \\
(0.0020)\end{array}$ & \\
\hline Std. Dev: Avg Summer Temperature & $\begin{array}{c}0.0522 \\
(0.0060)\end{array}$ & & $\begin{array}{c}0.0536 \\
(0.0059)\end{array}$ & & $\begin{array}{c}0.0527 \\
(0.0059)\end{array}$ & \\
\hline $\begin{array}{l}\text { Correlation Coefficient } \\
\text { PANEL B: 2nd Stage Estimates }\end{array}$ & -0.8332 & & -0.8273 & & -0.8257 & \\
\hline Variable & $\begin{array}{c}\text { Coef } \\
\text { (Std Err) }\end{array}$ & $\begin{array}{l}\text { MWTP } \\
\text { (Std Err) }\end{array}$ & $\begin{array}{c}\text { Coef } \\
\text { (Std Err) }\end{array}$ & $\begin{array}{l}\text { MWTP } \\
\text { (Std Err) }\end{array}$ & $\begin{array}{c}\text { Coef } \\
\text { (Std Err) }\end{array}$ & $\begin{array}{l}\text { MWTP } \\
\text { (Std Err) }\end{array}$ \\
\hline Mean: Avg Winter Temperature & $\begin{array}{c}0.0249 \\
(0.0056)\end{array}$ & $\begin{array}{c}\$ 709 \\
(\$ 160)\end{array}$ & $\begin{array}{c}0.0253 \\
(0.0055)\end{array}$ & $\begin{array}{c}\$ 588 \\
(\$ 136)\end{array}$ & $\begin{array}{c}0.0226 \\
(0.0057)\end{array}$ & $\begin{array}{c}\$ 885 \\
(\$ 247)\end{array}$ \\
\hline Mean: Avg Summer Temperature & $\begin{array}{l}-0.0307 \\
(0.0091)\end{array}$ & $\begin{array}{l}-\$ 873 \\
(\$ 260)\end{array}$ & $\begin{array}{l}-0.0319 \\
(0.0091)\end{array}$ & $\begin{array}{l}-\$ 740 \\
(\$ 220)\end{array}$ & $\begin{array}{l}-0.0256 \\
(0.0093)\end{array}$ & $\begin{array}{c}-\$ 1,004 \\
(\$ 402)\end{array}$ \\
\hline July Humidity & $\begin{array}{l}-0.0269 \\
(0.0049)\end{array}$ & $\begin{array}{l}-\$ 764 \\
(\$ 142)\end{array}$ & $\begin{array}{l}-0.0264 \\
(0.0049)\end{array}$ & $\begin{array}{l}-\$ 614 \\
(\$ 121)\end{array}$ & $\begin{array}{l}-0.0296 \\
(0.0050)\end{array}$ & $\begin{array}{c}-\$ 1,160 \\
(\$ 224)\end{array}$ \\
\hline Annual Snowfall & $\begin{array}{l}-0.0166 \\
(0.0024)\end{array}$ & $\begin{array}{r}-\$ 471 \\
(\$ 70)\end{array}$ & $\begin{array}{l}-0.0166 \\
(0.0024)\end{array}$ & $\begin{array}{l}-\$ 385 \\
(\$ 61)\end{array}$ & $\begin{array}{l}-0.0169 \\
(0.0024)\end{array}$ & $\begin{array}{l}-\$ 662 \\
(\$ 110)\end{array}$ \\
\hline Ln(Summer Precipitation) & $\begin{array}{c}0.1408 \\
(0.0720)\end{array}$ & $\begin{array}{c}\$ 376 \\
(\$ 192)\end{array}$ & $\begin{array}{r}0.1433 \\
(0.0716)\end{array}$ & $\begin{array}{c}\$ 312 \\
(\$ 161)\end{array}$ & $\begin{array}{r}0.1495 \\
(0.0737)\end{array}$ & $\begin{array}{l}\$ 550 \\
(\$ 297)\end{array}$ \\
\hline Annual Sunshine & $\begin{array}{l}-0.0155 \\
(0.0057)\end{array}$ & $\begin{array}{l}-\$ 441 \\
(\$ 162)\end{array}$ & $\begin{array}{l}-0.0143 \\
(0.0056)\end{array}$ & $\begin{array}{l}-\$ 331 \\
(\$ 136)\end{array}$ & $\begin{array}{l}-0.0183 \\
(0.0059)\end{array}$ & $\begin{array}{l}-\$ 716 \\
(\$ 253)\end{array}$ \\
\hline
\end{tabular}

Note: When entering the regressions non-linearly, amenity variables are evaluated at population-weighted means in order to compute MWTP. Non-linear covariates are the following: population density, summer precipitation, and elevation enter in log form while distance to the coast enters the model quadratically. 


\section{Appendix B}

Derivation of Model 10 (Housing Price Index in Stage 2)

Suppose household $i$ maximizes a Cobb-Douglas utility function

$$
U_{i j}=C_{i j}^{\alpha_{C}} H_{i j}^{\alpha_{H}} e^{M C_{i j}} e^{A_{j} \boldsymbol{\beta}_{i}}
$$

subject to a budget constraint $C_{i j}+\rho_{j} H_{i j}=Y_{i j}$ where $C_{i j}$ is consumption of a composite good in city $j, H_{i j}$ is housing, $\rho_{j}$ is a city-specific housing price index, and all other variables are as previously defined. Substituting optimal values for $C_{i j}$ and $H_{i j}$ and taking logs yields the indirect utility for household $i$ living in city $j^{32}$

$$
\ln V_{i j}=\alpha_{0}+\alpha_{Y} \ln Y_{i j}+M C_{i j}-\alpha_{H} \ln \rho_{j}+\boldsymbol{A}_{j} \boldsymbol{\beta}_{i}
$$

where $\alpha_{Y}=\alpha_{C}+\alpha_{H}$. Combining all terms that vary only by MSA gives an alternative specification for indirect utility:

$$
\ln V_{i j}=\alpha_{0}+\alpha_{Y} \ln Y_{i j}+M C_{i j}+\delta_{j}^{\prime}
$$

where $\delta_{j}^{\prime}=-\alpha_{H} \ln \rho_{j}+\boldsymbol{A}_{j} \boldsymbol{\beta}_{i}$. First stage estimation proceeds via simulated maximum likelihood as in our base case.

In the second stage, we would like to regress the estimated MSA fixed effects $\left(\hat{\delta}_{j}^{\prime}\right)$ on the housing price index and local amenities according to the following regression:

$$
\hat{\delta}_{j}^{\prime}=-\alpha_{H} \ln \rho_{j}+\boldsymbol{A}_{j} \boldsymbol{\beta}_{i}+\eta_{i j}
$$

However, $\rho_{j}$ is likely to be correlated with the error term $\eta_{i j}$. Thus, we rearrange and estimate the following equation

$$
\hat{\delta}_{j}^{\prime}+\alpha_{H} \ln \rho_{j}=\boldsymbol{A}_{j} \boldsymbol{\beta}_{i}+\eta_{i j}
$$

recalling that $\rho_{j}$ is the estimated fixed effect from a national hedonic regression of housing expenditures on housing characteristics and that, by the properties ofCobb-Douglas utility, we have that $\alpha_{H} / \alpha_{Y}$ is the proportion of income spent on housing. Thus, multiplying the median

\footnotetext{
$32 \alpha_{0}=\alpha_{C}\left(\frac{\alpha_{C}}{\alpha_{C}+\alpha_{H}}\right)+\alpha_{H}\left(\frac{\alpha_{H}}{\alpha_{C}+\alpha_{H}}\right)$
} 
share of income spent on housing (0.25) from our sample of households by $\hat{\alpha}_{Y}$ (estimated in the first stage) gives us an estimate for $\alpha_{H}$ 